\title{
Quality attributes of lamb meat from European breeds: Effects of intrinsic properties and storage
}

\author{
Ursula Gonzales-Barron ${ }^{\mathrm{a}}$, Gisela Santos-Rodrigues ${ }^{\mathrm{a}}$, Roberto Bermúdez Piedra ${ }^{\mathrm{b}}$, \\ Sara Coelho-Fernandes ${ }^{a}$, Koldo Osoro ${ }^{c}$, Rafael Celaya ${ }^{c}$, Raimundo Serrão Maurício ${ }^{\mathrm{d}}$, \\ Jaime Pires $^{\mathrm{d}}$, Anna Tolsdorf ${ }^{\mathrm{e}}$, Andreas Geß ${ }^{\mathrm{e}}$, Francesco Chiesa ${ }^{\mathrm{f}}$, Mirian Pateiro ${ }^{\mathrm{b}}$, \\ Alberto Brugiapaglia $^{\mathrm{f}, \mathrm{g}}$, Raúl Bodas ${ }^{\mathrm{h}}$, Mario Baratta ${ }^{\mathrm{f}}$, José M. Lorenzo ${ }^{\mathrm{b}, \mathrm{i}}$, Vasco A. \\ P. Cadavez ${ }^{\text {a,d }, *}$ \\ ${ }^{a}$ Centro de Investigação de Montanha (CIMO), Instituto Politécnico de Bragança, 5300-253 Bragança, Portugal

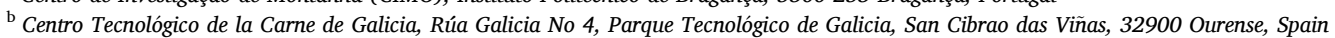 \\ ${ }^{\mathrm{c}}$ Servicio Regional de Investigación y Desarrollo Agroalimentario (SERIDA), Ctra. AS-267 PK 19, 33300 Villaviciosa, Asturias, Spain \\ ${ }^{\mathrm{d}}$ Escola Superior Agrária, Instituto Politécnico de Bragança, 5300-253 Bragança, Portugal \\ ${ }^{\mathrm{e}}$ Department Life Cycle Engineering (GaBi), Institute for Acoustics and Building Physics, Stuttgart University, 70563 Stuttgart, Germany \\ ${ }^{\mathrm{f}}$ Department of Veterinary Science, Università degli Studi di Torino, Turin, Italy \\ ${ }^{g}$ DISAFA, Università degli Studi di Torino, Turin, Italy \\ ${ }^{\mathrm{h}}$ Instituto Tecnológico Agrario de Castilla y León, Leon, Spain \\ ${ }^{\text {i }}$ Área de Tecnología de los Alimentos, Facultad de Ciencias de Ourense, Universidad de Vigo, 32004 Ourense, Spain
}

\section{A R T I C L E I N F O}

\section{Keywords:}

Sheep

Local breeds

Meat maturation

Tenderness

Lipid oxidation

Water holding capacity

\begin{abstract}
A B S T R A T
The sustainability of the European sheep farming sector can be ensured through the high and consistent quality of products, although the concept of meat quality, being multifaceted, is challenging to keep up by farmers and producers. The objectives of this study were (i) to evaluate quality attributes (CIE $\mathrm{L}^{*}, \mathrm{a}^{*}, \mathrm{~b}^{*}$, lipid oxidation, cooking loss and Warner-Bratzler texture test) of lamb meat during cold storage originating from eight European breeds raised under their normal production systems $(n=292$ lambs); and (ii) to elucidate the influence of storage and intrinsic properties (cold carcass weight [CCW], ultimate $\mathrm{pH}\left[\mathrm{pH}_{24}\right]$, water activity $\left[\mathrm{a}_{\mathrm{w}}\right]$, and proximate composition) on the aforementioned quality attributes measured on the 3rd, 9th and 15th day post slaughter. All meat quality properties displayed a high variability due to the breed $\times$ production systems, although, as a whole, $L^{*}, a^{*}, b^{*}$, TBARs and cooking loss increased during storage $(P<0.001)$, whereas the tenderisation process was of non-linear decay nature $(P=0.001)$. While production system - taken across breeds - was not found to affect meat cooking losses, it heavily influenced CCW, producing intensive systems heavier $(P<0.001)$ carcasses $(21.4 \mathrm{~kg})$ than those raised in semi-extensive $(14.9 \mathrm{~kg})$ and extensive systems $(13.8 \mathrm{~kg})$. On the 15th day of storage, TBARs from intensive systems was significantly $(P<0.001)$ higher than those of extensively raised lambs $(0.839 \mathrm{mg}$ MDA/ $\mathrm{kg}$ vs. $0.299 \mathrm{mg} \mathrm{MDA} / \mathrm{kg}$, respectively). Although the extensive and semi-extensive systems initially produced less tender meat $(P<0.05)$ than intensive systems, on the 15 th day of storage, meat from extensive $\left(23.4 \mathrm{~N} / \mathrm{cm}^{2}\right)$ and semi-extensive systems $\left(24.4 \mathrm{~N} / \mathrm{cm}^{2}\right)$ presented as good tenderness quality $(P<0.10)$ as that of the intensive systems $\left(22.1 \mathrm{~N} / \mathrm{cm}^{2}\right)$. Within breed $\times$ production systems, higher CCW or intramuscular fat was associated to darker meat $(P<0.001$ and $P=0.014)$, higher redness $(P<0.001$ for both), greater lipid oxidation $(P=0.016$ and $P<0.001)$, and lower slope $(P=0.014$ and $P=0.004)$ and force $(P=0.027$ and $P=0.001)$. The only intrinsic property that heavily affected most of the quality attributes was ash content, since meat of higher ash content presented higher luminosity $(P=0.008)$, and lower redness $(P<0.001)$, yellowness $(P<0.001)$, TBARS $(P<0.001)$, cooking loss $(P=0.002)$ and tenderness $(P<0.001)$. The elucidation of the impact of intrinsic properties on the lamb meat quality attributes during
\end{abstract}

\footnotetext{
* Corresponding author.

E-mail address: vcadavez@ipb.pt (V.A.P. Cadavez).
} 
storage can help breeders and producers modify current flock management, feeding strategies and pre-slaughter and slaughter practices towards quality improvement or meeting particular consumers' demands.

\section{Introduction}

A renewed interest in local sheep breeds has been prompted by the EU's recent promotion of a sustainable development of otherwise marginal areas and policies supporting extensive systems of animal production (Montossi et al., 2013; Paraskevopoulou et al., 2020). Local sheep production is more likely to be found in low farming areas, where sheep graze semi-natural vegetation and are dominant with other low input extensive grazing livestock (Cruz et al., 2019). Even though sheep farming represents only a small contribution to Europe's gross domestic product $(<0.5 \%$, Eurostat, 2019), the sector is of great importance to rural development and the environment. The indigenous sheep breeds, in addition to contributing to the diversity of production systems, are important genetic resources that must be preserved because of their local adaptation, disease resistance, high fertility and unique product qualities (Mendelsohn, 2003). Some of these breeds have small body size and good adaptation to adverse climatic and orographic environments, which makes them particularly suited to the use and enhancement of natural pastures (Cruz et al., 2019). In addition, in the EU there is a vast range of sheep breeds used and a wide range of management practices adopted, all of which make sheep farming enormously rich in diversity (De-Arriba and Sánchez-Andrés, 2014).

One strategy for attaining sustainability of the local sheep farming sector is through quality of products (Erasmus et al., 2017). Enhancing the quality of meat from autochthonous breeds, making it more attractive to consumers, could contribute to the preservation of the rural world and its diversity, the conservation of endangered breeds, as well as improving the profitability and living standards of the sheep farmers that remain in the rural areas of Europe (Bernués et al., 2011). Nonetheless, meat quality is a very ample concept defined by industry and the final consumer, which is regulated by a series of factors that are intrinsic and extrinsic to the animal (Webb et al., 2005). In the context of the supply chain and meat science, the analysis of colour, $\mathrm{pH}$, water holding capacity, tenderness and chemical composition are important quality attributes. Consequently, it is necessary to understand how the intrinsic properties of carcass and meat affect or determine the quality attributes of meat, so that producers of native breeds can optimise lamb meat quality, and face the challenges imposed by the heterogeneity of stakeholders, as well as the challenges of products of homogeneous quality, often sought by the consumers.

Therefore, the objective of this study was twofold: (i) to evaluate the evolution of quality attributes (colour, lipid oxidation, cooking loss and texture) of refrigerated vacuum-packed (VP) lamb meat originating from ten farms housing eight European breeds raised in intensive, extensive or semi-extensive regime; and (ii) to elucidate, by means of mixed models, the effects of cold storage and carcass/meat's intrinsic properties (i.e., cold carcass weight, ultimate $\mathrm{pH}$, water activity, moisture content, fat content, protein content and ash content) on the aforementioned quality attributes of lamb meat. Eight sheep breeds exploited for meat production were utilised in the present study: ChurraGalega-Bragançana (CGB) and Bordaleira-de-Entre-Douro-e-Minho (BEDM) from the Mediterranean and the Atlantic bioregions of Portugal, respectively; Castellana and INRA401 from the Mediterranean bioregion of Spain; Gallega from the Atlantic bioregion of Spain; Biellese and Sambucana from the Continental and the Alpine bioregions of Italy, respectively; and crossbred Texel-Merino-Blackhead (TMB) from the Continental bioregion of Germany.

\section{Material and methods}

\subsection{Lamb rearing and feeding}

All animals' management and procedures were carried out in accordance with EU Directive 2010/63/EU for animal experiments.

\subsubsection{Portugal}

In the Mediterranean region, located in Bragança, CGB lambs were raised on the holding of the School of Agriculture of the Polytechnic Institute of Bragança. In the Atlantic bioregion, located in Ponte de Lima, BEDM lambs were raised on the holding of the Ponte de Lima Agrarian School. The production system used for BEDM lambs was the extensive one, while for CGB lambs the semi-extensive system, whose feeding was based on grazing on natural pastures. The hours of grazing varied according to hours of light, heat and herd size. During winter, the flocks would be released in the morning to graze all day until dark. During summer, the herds would leave at dawn and graze until midmorning; they then would be put in a stable under shade; and would come out when the heat had subsided. Once on the premises, all lambs had access to meadow hay and water ad libitum, but the semi-extensively raised lambs were also supplemented with protein and mineral-rich concentrates. The lambs were not weaned, and were reared in the fall of 2018 and spring 2019. For this investigation, 15 BEDM and 15 CGB lambs were slaughtered in 2018 and 15 BEDM and 15 CGB lambs were slaughtered in 2019.

\subsubsection{Spain}

In the Mediterranean regions of Salamanca and Zamora, INRA401 and Castellana breed lambs, respectively, were raised under an intensive system on commercial farms. Lambs were weaned when they were 4-6 weeks old and housed with straw bedding and free access to commercial concentrate, cereal straw and fresh water. In Valladolid, Castellana breed lambs were raised under a semi-extensive system. Animals were weaned at 4-6 weeks old and housed together with straw bedding, allowed to graze outdoors (pastures were predominately oak and pine forests, cereal stubbles and vineyards) during the morning; and they were kept indoors during the afternoon and night, with free access to commercial concentrate, cereal straw and fresh water. Fourteen INRA401 and 15 Castellana (from Zamora) lambs were reared in the spring of 2018, while 30 Castellana lambs ( 15 from Zamora and 15 from Valladolid) were reared in the spring of 2019.

In the Atlantic bioregion of Asturias, lambs were reared with their dams at the SERIDA experimental farm. Lambs of Gallega breed were born during winter, grown suckling their mothers on pasture, and weaned in late spring-early summer before their slaughter at an age of 4-5 months. Lambs (36 in 2018 and 48 in 2019) were raised in an extensive system on 12 experimental paddocks (half with apple trees) sown with perennial ryegrass (Lolium perenne) and white clover (Trifolium repens) and organically managed (without synthetic fertilisers), where grazing season started in early April. In 2019, another lot of 12 lambs were managed in a semi-extensive system on pasture supplemented with concentrate feeding offered in troughs since late April.

\subsubsection{Italy}

In the Continental bioregion, located in Turin, Biellese lambs were raised in CISRA, Teaching Animal Farm of the Veterinary Science Department, University of Turin. In the Alpine bioregion, located in Val Maira, Western Alps, at an altitude of 1800-2000 m, Sambucana lambs were bred during the summer season. The production system used for Biellese breed was semi-extensive (i.e., the lambs consumed about $500 \mathrm{~g}$ 
of milk per day, after weaning (day 60 ), they were fed with $\sim 150 \mathrm{~g}$ of concentrate per day and hay ad libitum until the slaughtering), while the production system for Sambucana lambs was based on grazing on natural pasture. In the semi-extensive system for Biellese lambs, the flocks would be released to graze outside in autumn-winter season (period of investigation); whereas in the extensive system, Sambucana lambs would leave at dawn and graze until evening; then they would be recovered in a fence in summer season (period of investigation). The lambs were not weaned during the grazing season in the Alpine bioregion. For this investigation, 16 Biellese and 20 Sambucana lambs were reared in 2018, and 12 Biellese and 12 Sambucana lambs were reared in 2019.

\subsubsection{Germany}

Crossbred Texel-Merino-Blackhead-Charollais (TMB) lambs were raised on a farm near Münsingen, belonging to the Continental bioregion of Germany. These farmers work with a mid-sized flock of around 500 ewes. The study pasture of $170 \mathrm{Ha}$ is managed extensively. The insemination is carried out naturally in spring. During winter, traditional transhumance is practiced to the lower Swabian areas of Nördlingen. The sheep graze all year long. Additionally, mineral-rich feed is provided. For this experiment, 15 lambs were reared in 2018 and 14 lambs in 2019.

\subsection{Preparation of lamb meat samples}

All lambs were four-to-five months old when slaughtered. Lambs were slaughtered in batches ranging from 5 to 15 animals in local abattoirs of Portugal, Spain, Italy and Germany, and the whole experiment was conducted in the fall and spring seasons of 2018 and 2019. A total of 292 lambs were employed in this study, from the following breeds and production systems: BEDM extensive (28), Biellese semi-extensive (28), Castellana intensive (30), Castellana semi-extensive (15), CGB semiextensive (30), Gallega extensive (74), Gallega semi-extensive (12), INRA401 intensive (14), Sambucana extensive (32) and TMB extensive (29)

In the slaughterhouses, lamb carcasses obtained were chilled at $4{ }^{\circ} \mathrm{C}$, and cold carcass weight (CCW) was recorded after $24 \pm 1 \mathrm{~h}$. After carcass splitting, the right Longissimus lumborum was divided into three parts, and vacuum packed in transparent gas-tight polyamide and polyethylene vacuum bags (Orved $\AA$, Spain, with permeability of $84 \pm 4.20 \mathrm{cc} / \mathrm{m}^{2} / 24 \mathrm{~h} /$ atm for $\mathrm{O}_{2}, 361 \pm 18.05 \mathrm{cc} / \mathrm{m}^{2} / 24 \mathrm{~h} / \mathrm{atm}$ for $\mathrm{CO}_{2}, 22 \pm 1.10 \mathrm{cc} / \mathrm{m}^{2} / 24 \mathrm{~h} / \mathrm{atm}$ for $\mathrm{N}_{2}$ and $9.0 \pm 0.45 \mathrm{cc} / \mathrm{m}^{2} / 24 \mathrm{~h} / \mathrm{atm}$ for $\mathrm{H}_{2} \mathrm{O}$ and density of $\pm 100 \mu \mathrm{m}$ ). Each bag was labelled with the number 3,9 or 15 , corresponding to the day of analysis of colour in CIE $L^{*}, a^{*}, b^{*}$ parameters, concentration of thiobarbituric acid reactive substances (TBARs), cooking loss and Warner-Bratzler texture parameters. These properties, carried out at three time points during storage, will be referred to as meat quality attributes.

The left half of the L. lumborum muscle was removed from the $6^{\text {th }}$ to the $13^{\text {th }}$ vertebra, vacuum-packed and subjected to physicochemical analyses - ultimate $\mathrm{pH}$, water activity, and proximate composition (moisture and dry matter, intramuscular fat content [IMF], protein content and ash content) - which were carried out on day 1 after slaughter. These physicochemical analyses, carried out only once at the beginning of cold storage, will be hereafter referred to as intrinsic properties of meat. Until the day of analysis, meat samples were kept at $4 \pm 0.5^{\circ} \mathrm{C}$ in calibrated laboratory refrigerators. All the essays were carried out in the same laboratory.

\subsection{Analysis of meat quality attributes}

The $\mathrm{pH}$ was measured in triplicate using a digital portable $\mathrm{pH}$-meter (Hanna Instruments, Eibar, Spain) equipped with a penetration glass probe. A portable colorimeter (Konica Minolta CR-600d, Osaka, Japan) was used to measure in triplicate the meat colour in the CIELAB space (lightness $\mathrm{L}^{*}$, redness $\mathrm{a}^{*}$ and yellowness $\mathrm{b}^{*}$ ). The device was set to pulsed xenon arc lamp, $10^{\circ}$ viewing angle geometry, standard illuminant D65 and aperture size of $8 \mathrm{~mm}$. Samples were allowed to bloom for $30 \mathrm{~min}$ before measuring. The water holding capacity was measured as cooking loss. Samples were cooked using vacuum package bags in a water bath with automatic temperature control (JP Selecta, Precisdg, Barcelona, Spain) until they reached an internal temperature of $70^{\circ} \mathrm{C}$, controlled by thermocouples type K (Comark, PK23 M, UK), connected to a data logger (Comark Dilligence EVG, N3014, UK). After cooking, samples were cooled at room temperature during a period of $\sim 30 \mathrm{~min}$ and the percentage of cooking loss was calculated by determining the difference in weight between the cooked and raw samples. This analysis was performed in duplicate.

A texture analyser (TA.XT.plus, Stable MicroSystems, Vienna Court, UK) was used to carry out the Warner-Bratzler (WB) test. For every meat sample, six subsamples of $1 \times 1 \times 2.5 \mathrm{~cm}$ (height $\times$ width $\times$ length) were removed parallel to the muscle fibre direction. Subsamples were completely cut perpendicular to the muscle fibre direction using a WB shear blade with a triangular slot cutting edge (1 mm thickness) at a crosshead speed of $3.33 \mathrm{~mm} / \mathrm{s}$. Maximum shear force, shear firmness and total work necessary to cut the sample were obtained.

The evaluation of lipid stability was assessed by measuring TBARs values following the method proposed by Vyncke (1975). Briefly, the sample $(2 \mathrm{~g})$ was dispersed in $5 \%$ trichloroacetic acid $(10 \mathrm{~mL})$ and homogenised in an Ultra-Turrax (IkaT25 basic, Staufen, Germany) for $2 \mathrm{~min}$. The homogenate was maintained at $-10{ }^{\circ} \mathrm{C}$ for $10 \mathrm{~min}$ and centrifuged at $2360 \times \mathrm{g}$ for $10 \mathrm{~min}$. The supernatant was filtered through Whatman No. 1 paper. The filtrate $(5 \mathrm{~mL})$ was reacted with a $0.02 \mathrm{M}$ TBA solution ( $5 \mathrm{~mL}$ ) and incubated in a water bath at $97^{\circ} \mathrm{C}$ for $40 \mathrm{~min}$. The absorbance was measured at $532 \mathrm{~nm}$. The TBARs value was calculated from a standard curve of malonaldehyde with 1,1-3,3 tetraethoxypropane, and expressed as mg malonaldehyde (MDA) per $\mathrm{kg}$ of sample. This analysis was carried out in duplicate.

\subsection{Physicochemical analyses of meat}

The meat's intrinsic properties measured were ultimate $\mathrm{pH}\left(\mathrm{pH}_{24}\right)$, water activity $\left(\mathrm{a}_{\mathrm{w}}\right)$ and proximate composition. The $\mathrm{pH}$ measurement was carried out according to Pateiro et al. (2013), using a pH meter (HI 99163, Hanna Instruments, Eibar, Spain) connected to a 232D glass probe with a stainless-steel penetration blade. To measure $\mathrm{a}_{\mathrm{w}}$, lamb steaks were cut to exactly fit in the cuvette of the Aqualab water activity meter (4TE Decagon Devices Inc., Pullman, USA), previously calibrated with sodium chloride, and the value was recorded after measurement stabilisation. Moisture, IMF, protein and ash contents were determined according to ISO 1442 (1997); AOCS (2005); ISO 937 (1978) and ISO 936 (1998), respectively. Determinations were made in duplicate per meat sample. Contents of IMF, protein and ashes were expressed in dry basis.

\subsection{Statistical analysis}

The statistical analysis aimed to understand to what extent the CCW and the intrinsic properties of meat $\left(\mathrm{pH}_{24}, \mathrm{a}_{\mathrm{w}}\right.$ and proximate composition) can affect its quality attributes, as characterised by the change in $L^{*}, a^{*}, b^{*}$ colour coordinates, TBARs, cooking loss and WB slope, work and force (8 quality attributes) during cold storage.

A general mixed-effects model of the type,

$Y_{r(j)}=\beta_{0 r(j)}+\beta_{1} X+\beta_{2}($ Day $)+\beta_{3}$ Day $^{2}+\varepsilon_{r(j)}$ $\beta_{0 r(j)}=\beta_{0}+u_{0 r}+v_{0 r(j)}$

was adjusted to each of the quality attributes $(Y)$ to assess the effect of time of storage (Day) and the effect of each of the intrinsic properties of meat $(X)$, in separate. The response variable $Y_{r(j)}$ is the quality attribute measured in the meat sample from lamb $j$ belonging to farm $r$, measured 


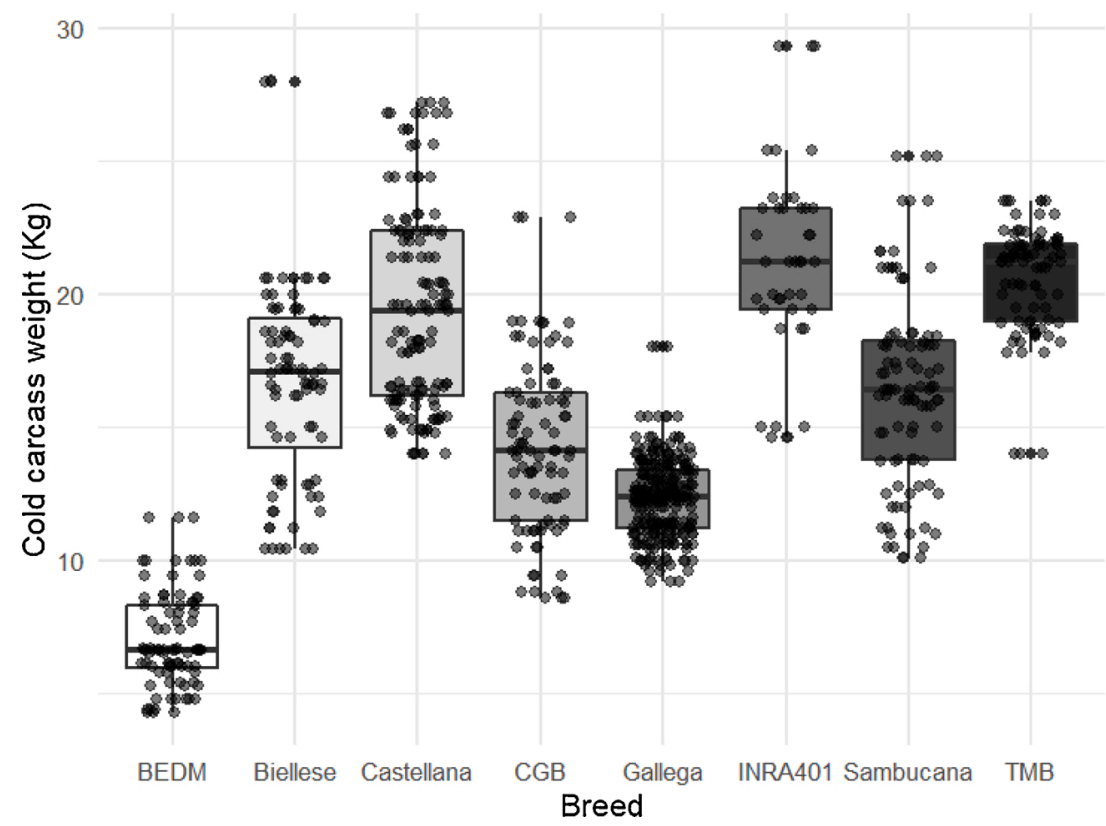

Fig. 1. Box plots of cold carcass weight (CCW) of lambs from different European breeds, measured $24 \mathrm{~h}$ after slaughter.

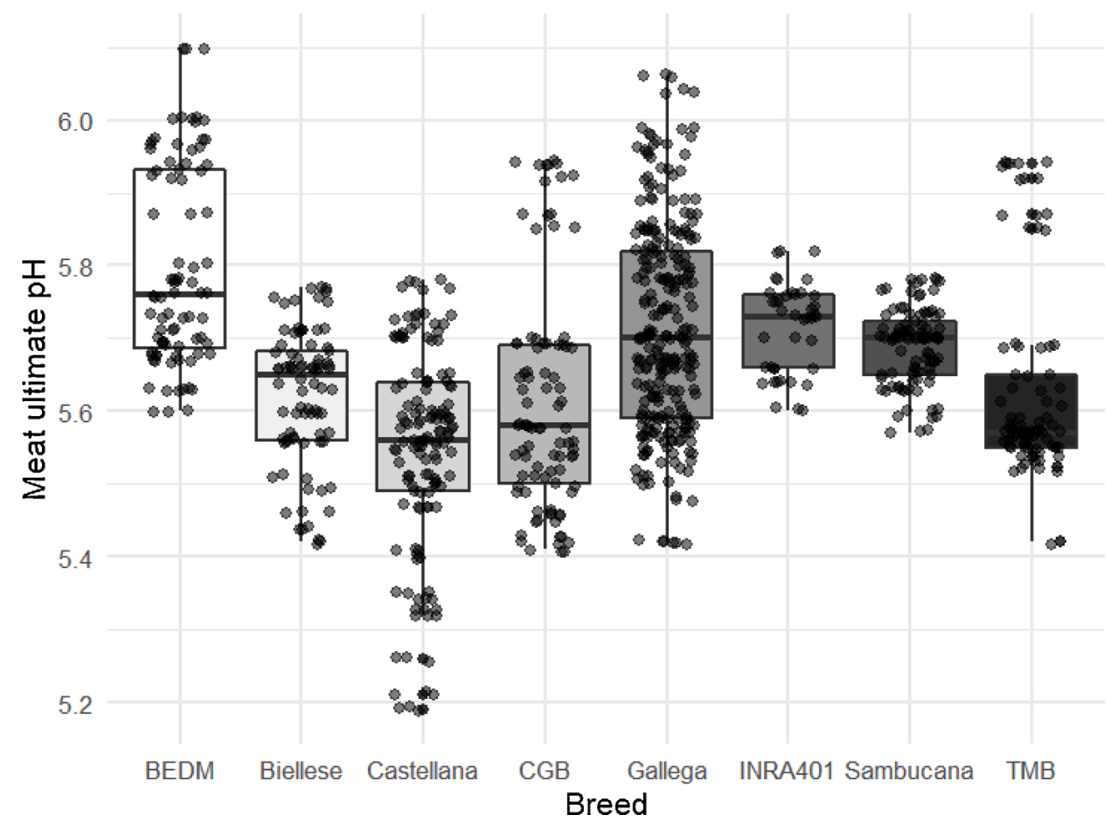

Fig. 2. Box plots of ultimate $\mathrm{pH}\left(\mathrm{pH}_{24}\right)$ of lambs from different European breeds, measured $24 \mathrm{~h}$ after slaughter.

after storage time Day. Day was entered in the model as a repeated measures factor. A sheep farm is defined by a local breed raised under certain production system, which amounted to 10 farms in this study: BEDM - extensive, CGB - semi-extensive, Castellana - intensive, Castellana - semi-extensive, Gallega - extensive, Gallega - semi-extensive, INRA401 - intensive, Biellese - semi-extensive, Sambucana - extensive, and TMB - extensive.

The parameter $\beta_{1}$ is the fixed effect of the intrinsic property on the quality attribute, whereas $\beta_{2}$ is the fixed effect for the storage time, Day. A quadratic effect for Day $\left(\beta_{3}\right)$ was added only to the models for WB slope, work and force, since this term was significant only for these quality attributes $\left(\beta_{3}\right.$ was set to zero in the models for $L^{*}, a^{*}, b^{*}$, TBARs and cooking loss). The mean intercept $\beta_{0}$ is affected by random shifts $u_{0 r}$ caused by the farm $r$, and $v_{0 r(j)}$ caused by the lamb $j$ nested within farm $r$. By using this random effects structure, the variability due to breed and due to lamb within breed is removed, so that the effect of the intrinsic property on the quality attribute of meat can be estimated with less noise. The nested intercept random effects $u_{0 r}$ and $v_{0 r(j)}$ were assumed to follow normal distributions. The term $\varepsilon_{r(j)}$ represents the model's residuals which are also assumed to follow a normal distribution.

Equation (1) was adjusted separately to each of the eight quality attributes $(Y)$, and, in each of the adjustments, the independent variable $X$ represents CCW, $\mathrm{pH}_{24}, \mathrm{a}_{\mathrm{w}}$, moisture, protein, IMF or ash content. Thus, in total 56 models were fitted. Nonetheless, these models were not intended for predicting quality attributes in time, but for inferring both the effects of the intrinsic properties of meat on the quality attributes, which were evaluated by the significance of the fitted parameter $\beta_{1}$, and the P-value of its respective F-test in analysis of variance (ANOVA). The models were adjusted in the $\mathrm{R}$ software version 1.0.136 (The $\mathrm{R}$ Core 

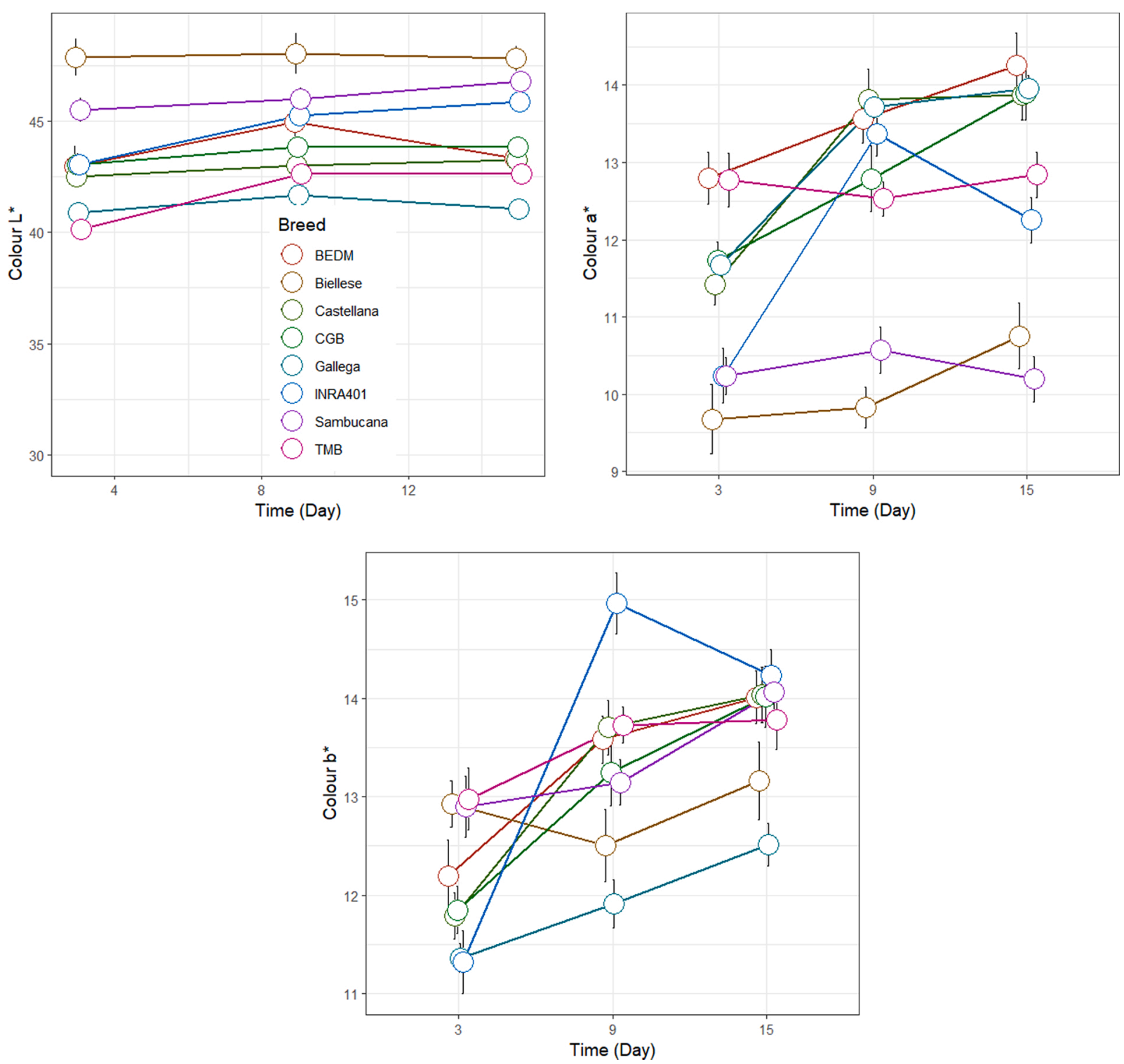

Fig. 3. Evolution of $\mathrm{L}^{*}, \mathrm{a}^{*}, \mathrm{~b}^{*}$ colour parameters of vacuum-packed lamb meat stored at $4{ }^{\circ} \mathrm{C}$ for the different European breeds.

Team, 2019).

\section{Results and discussion}

\subsection{Cold carcass weight and ultimate $\mathrm{pH}$}

The values of CCW and $\mathrm{pH}_{24}$ in lamb meat differed between breed $\times$ production systems (Fig. 1 and 2). The lowest mean CCW values were registered for BEDM $(7.03 \mathrm{~kg}$; $95 \%$ CI: $6.21-7.84 \mathrm{~kg})$, semiextensive Gallega (11.37 kg; 95\% CI: $10.12-12.61 \mathrm{~kg}$ ) and extensive Gallega (12.52 kg; 95\% CI; 12.02-13.02 kg), whereas the highest CCW mean values were observed in the lambs from TMB $(20.59 \mathrm{~kg}$; $95 \% \mathrm{CI}$ : 19.79-21.39 kg), INRA401 (21.20 kg; 95\% CI: $20.05-22.35 \mathrm{~kg})$ and intensive Castellana breeds (21.45 kg; 95\% CI: $20.66-22.23 \mathrm{~kg}$ ). Midsized carcasses in the mean range of $14.28-16.76 \mathrm{~kg}$ were found for CGB, semi-extensive Castellana, Sambucana and Biellese (Fig. 1). In general, lambs raised in intensive systems $(21.4 \mathrm{~kg}$; 95\% CI: 20.5-22.3 $\mathrm{Kg})$ produced significantly $(P<0.05)$ heavier carcasses than those raised in semi-extensive (14.9 kg; 95\% CI: $14.3-15.5 \mathrm{~kg}$ ) and extensive (13.8 kg; 95\% CI: 13.3-14.2 kg) systems. Similar results were observed by other authors in lambs fed with concentrate or grazing-based systems
(Borton et al., 2005; Ekiz et al., 2013).

Ultimate $\mathrm{pH}$ greatly affects meat quality and is dependent on the preslaughter glycogen concentration in muscle (De La Fuente et al., 2010; Islam et al., 2019). As stated by Gallo et al. (2019), in recently slaughtered lambs, $\mathrm{pH}$ is around 7.0-7.3, and declines up to 5.5-5.8 after $24 \mathrm{~h}$. The mean $\mathrm{pH}_{24}$ measured in this study fell within the range of 5.54 and 5.80 (Fig. 2), which would be normal values suggesting no DFD (dark, firm, dry) quality issues for the lamb meat. The meat from semi-intensive and intensive Castellana farms presented the lowest mean $\mathrm{pH}_{24}$ (5.539; 95\% CI: 5.485-5.592 and 5.548; 95\% CI: 5.510-5.586, respectively) whereas that of extensive Gallega (5.730; 95\% CI: 5.706-5.754) and BEDM farms (5.798; 95\% CI: 5.759-5.838) presented the highest mean $\mathrm{pH}_{24}$. Ball et al. (1998) attributed the greater $\mathrm{pH}$ value of young animals $(\mathrm{pH}>5.80)$ to their higher energy requirements, and therefore lower levels of reserves of glycogen before being slaughtered.

Although pH can be influenced by animal genetics (i.e., breed), there are other various factors that have an impact such as production system, feed and pre-slaughter treatment of the animals (Lind et al., 2011). For instance, the lowest variability in $\mathrm{pH}_{24}$ registered in the meat samples from INRA401, Sambucana and Biellese breeds (shorter boxplots in 

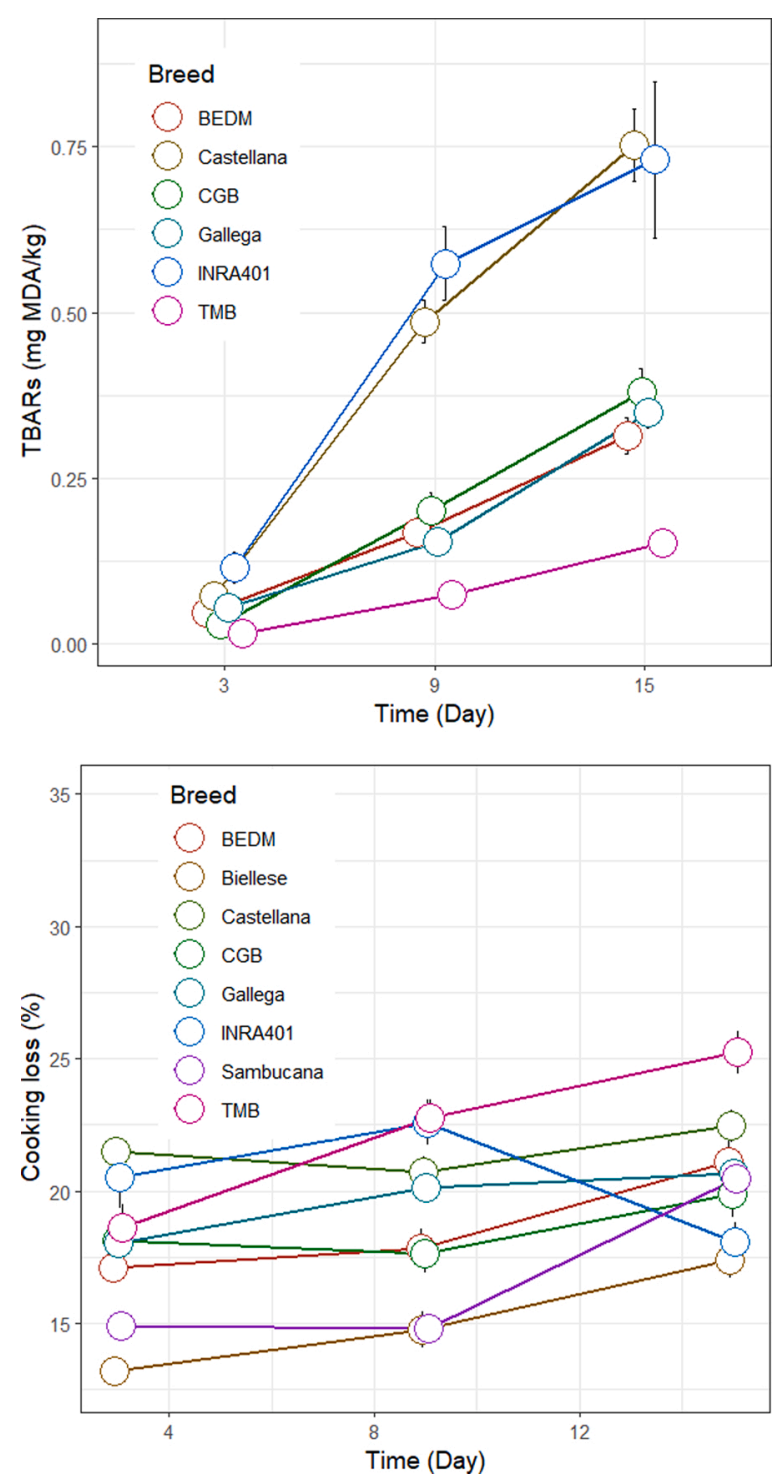

Fig. 4. Evolution of TBARs and cooking loss of vacuum-packed lamb meat stored at $4{ }^{\circ} \mathrm{C}$ for the different European breeds.

Fig. 2) could imply that more standardised flocks management and pre-slaughter conditions are employed in these farms. With respect to production system, no significant difference in meat $\mathrm{pH}_{24}$ was found between intensively (5.600; 95\% CI: 5.571-5.629) and semi-extensively raised lambs (5.604; 95\% CI: 5.583-5.625); nonetheless, meat from extensively raised lambs presented significantly higher $\mathrm{pH}_{24}$ (5.716; 95\% CI: 5.701-5.730). In line with our results, several studies have reported lower $\mathrm{pH}$ decline after $24 \mathrm{~h}$ in lambs reared on pasture than concentrate-based production systems (Ekiz et al., 2012a; Perlo et al., 2008). However, others did not find significant effect of the rearing conditions on $\mathrm{pH}_{24}$ (Ekiz et al., 2019; Popova and Marinova, 2013). The differences in $\mathrm{pH}_{24}$ could be explained with the variation in the muscle glycogen content at slaughter. According to Jacob et al. (2005), lambs finished on pasture had lower glycogen content in muscles when compared to lambs finished on grain-based diet.

In terms of meat $\mathrm{a}_{\mathrm{w}}$, high variability between breed $\times$ production systems was also observed. Whereas lamb meat from INRA401 (0.9888; 95\% CI: 0.9878 - 0.9898), intensive Castellana (0.9912; 95\% CI: 0.9906 - 0.9919) and semi-extensive Castellana farms (0.9914; 95\% CI: 0.9904 - 0.9923) presented the lowest $\mathrm{a}_{\mathrm{w}}$, meat from semi-extensively raised Gallega (0.9938; 95\% CI: 0.9928 - 0.9949) and extensively-raised TMB (0.9950; 95\% CI: $0.9944-0.9957)$ lambs presented the highest mean values. As with CCW, a trend in $\mathrm{a}_{\mathrm{w}}$ was also identified according to production system: meat from extensively-raised lambs presented significantly higher $\mathrm{a}_{\mathrm{w}}(0.9938$; 95\% CI: $0.9935-0.9941)$ than that of semi-extensively raised lambs (0.9926; 95\% CI: $0.9922-0.9931)$, which in turn were higher than that of intensively-raised lambs $(0.9905 ; 95 \%$ CI: $0.9899-0.9910)$. This may be a consequence of differences in moisture content of meat, since, as a whole, extensively-raised lambs (75.86; 95\% CI: 75.72-76.00\%) yielded meat of higher moisture than intensively-raised lambs (74.93\%; 95\% CI: 74.66-75.20\%).

The evolution of the quality attributes of meat such as colour (Fig. 3), lipid oxidation, cooking loss (Fig. 4) and WB texture (Fig. 5) was substantially affected by the breed $\times$ production system of the lambs. It is noteworthy to clarify that in the present study only the combined effect of both factors can be discussed since the examined breeds were reared under a particular production system to which they are best adapted and respond with the best performance and quality of meat. Thus, it is not possible to discern any effect of breed on lamb meat quality. Instead, its dependence on storage time and relationships with intrinsic factors such as $\mathrm{CCW}, \mathrm{pH}, \mathrm{a}_{\mathrm{w}}$ and proximate composition of meat will be discussed in the next Sections. Tables 1 and 2 compile the effects of these factors on the quality attributes of lamb meat as outcomes of the mixed models.

\subsection{Evolution of meat colour attributes during storage and their relation with the intrinsic properties of meat}

In general terms, the colour coordinates of meat, $\mathrm{L}^{*}, \mathrm{a}^{*}$ and $\mathrm{b}^{*}$, increased during cold storage (Fig. 3), as can be also deduced by the significant positive effect of Day in all mixed models $(P<0.001$; Table 1). Fig. 3 also depicts the difference in the instrumental colour of lamb meat due to breed $\times$ production system. As for $\mathrm{L}^{*}$ parameter, higher values (i.e., lighter colour) were measured in the lamb meat from Sambucana and Biellese farms, and lower values (i.e., darker colour) in the lamb meat from Gallega and TMB farms. Unlike $L^{*}$, with regards to redness ( $\left.a^{*}\right)$ and yellowness $\left(b^{*}\right)$, it was visually difficult to discriminate between the breed $\times$ production systems (Fig. 3). Moreover, there was no effect of production system $(P>0.10$, not shown) on the parameters $a^{*}$ or $b^{*}$. Likewise, Ekiz et al. (2019) could not find any effect of the production system either on $\mathrm{a}^{*}$ or on $\mathrm{b} *$ in lamb meat. On the contrary, Revilla et al. (2020) found rearing system had a significant effect $(P \leq 0.01)$ on colour parameters of Churra and Castellana breeds produced under organic and conventional systems. Similar outcomes were also found by Perlo et al. (2008) and Priolo et al. (2001), who reported higher $a^{*}$ and $b^{*}$ values in meat of grazing lambs, respectively.

Within breed $\times$ production systems, carcasses of higher CCW tended to produce lower $\mathrm{L}^{*}$ (i.e., low lightness) and higher $\mathrm{a}^{*}$ (i.e., high redness) $(P<0.001$ in both cases in Table 1$)$. The same relationship between animal weight and meat colour was reported by Beriain (1998), who observed that lamb meat from smaller carcasses presented lighter colour in comparison to lamb meat from heavier animals; and by Calnan et al. (2016), who indicated that increased IMF will make the bloomed colour of lamb meat redder. According to Ripoll et al. (2008) and Majdoub-Mathlouthi et al. (2013), $L^{*}$ decreases as slaughter weight increases. In fact, the concentration of myoglobin in muscle increases with the advance in the animal's physiological maturity (and IMF), and consequently, promotes an increase in meat's colour intensity (Dhanda et al., 2003; Domínguez et al., 2015). Calnan et al. (2016) explained that myoglobin has the greatest effect on $\mathrm{L}^{*}$, and they estimated a $3.1 \mathrm{~L}^{*}$-unit darkening of meat with increasing lamb age, accounted for by a higher concentration of myoglobin. Moreover, Molinero (2009) argued that the lower thickness of external fat of the carcass (linked to lighter carcasses) produces a reduction of moisture in the meat, which drives a decrease in its luminosity.

In fact, in our study, moisture content was found to be highly associated $(P<0.0001)$ with both $L^{*}$ and $a^{*}$. In this way, meat of greater moisture content presented higher $L^{*}$ (less dark) and lower a* (less reddish). Carrapiso and García (2005) observed the same association 

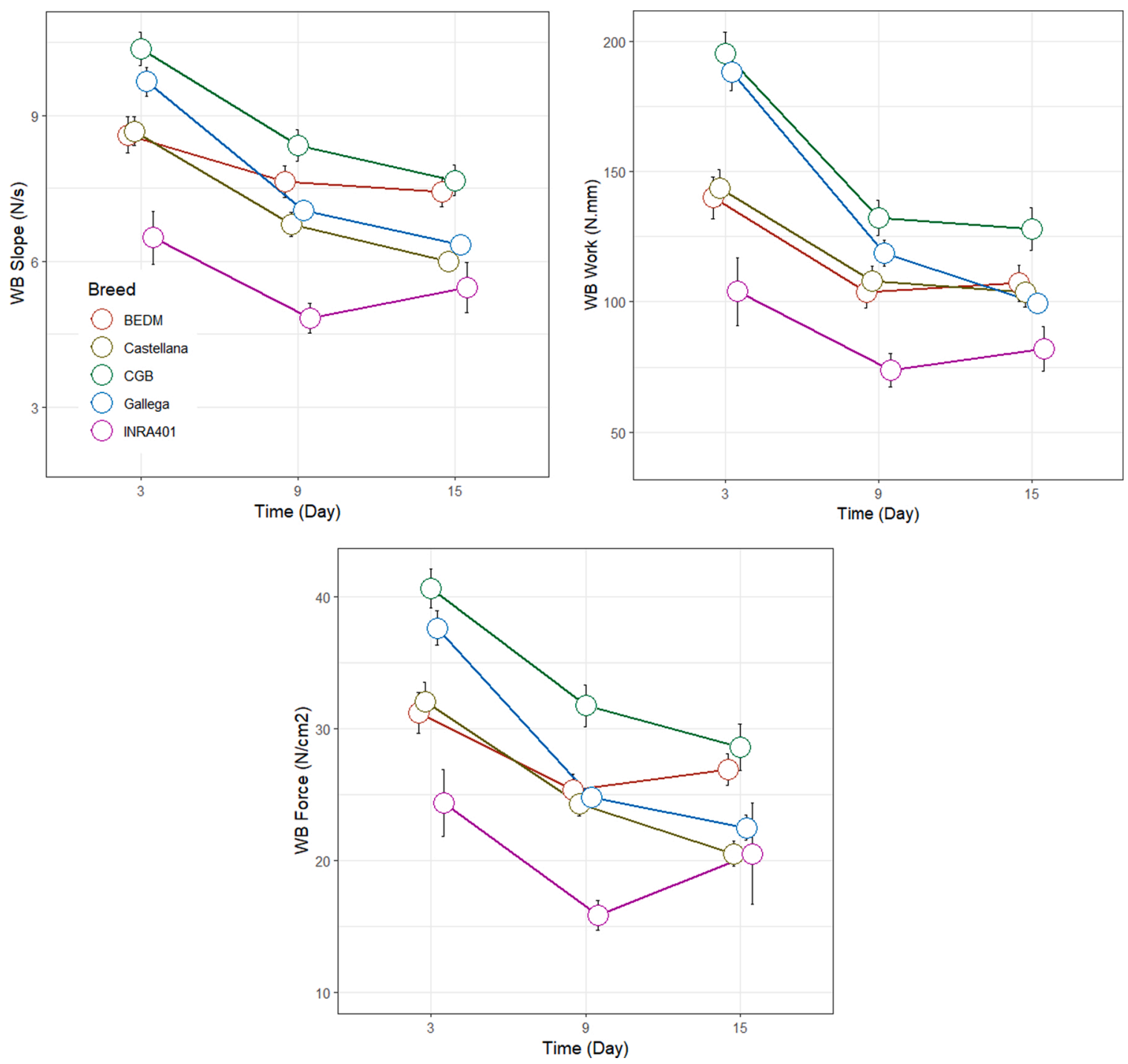

Fig. 5. Evolution of the Warner-Bratzler texture parameters of vacuum-packed lamb meat stored at $4{ }^{\circ} \mathrm{C}$ for the different European breeds.

between $\mathrm{L}^{*}$ and moisture in meat; and Ripoll et al. (2011) explained that greater retention of water content translates into meat of increased brightness. In the case of fat and ash content, both affected the values of $\mathrm{L}^{*}(P=0.014$ and $P=0.008)$ and $\mathrm{a}^{*}(P<0.0001)$. Lamb meat of greater IMF content was at the same time less luminous and more reddish (lower $\mathrm{L}^{*}$ and higher $\mathrm{a}^{*}$ ), which corroborated the results of Calnan et al. (2016), as earlier discussed. By contrast, lamb meat of greater ash content was high in lightness and low in redness. The impact of the levels of iron and copper on the oxymyoglobin/metmyoglobin ratio (i.e., retail colour) was earlier pointed out by Warner et al. (2010). Whereas protein content was not found to regulate $L^{*}(P=0.672)$, it was found to inversely affect $\mathrm{a}^{*}(P<0.0001$; Table 1$)$.

As expected, the colour parameters $L^{*}(P=0.050)$ and $a^{*}$ $(P=0.038)$ of lamb meat were affected by $\mathrm{pH}_{24}$ (Table 1$)$. Meat of lower $\mathrm{pH}$ displayed higher $\mathrm{L}^{*}$ and lower $\mathrm{a}^{*}$, and hence lighter bright red colour, which was reported in other studies (Perlo et al., 2008; Priolo et al., 2001). According to Calnan et al. (2016), changes in $\mathrm{pH}_{24}$ have the greatest effect on $\mathrm{a}^{*}$, which was also corroborated in our study. Water activity did not modulate either $\mathrm{L}^{*}(P=0.311)$ or $\mathrm{a}^{*}(P=0.228)$, yet it affected $b^{*}(P<0.001)$. The statistical analysis suggested that meat of higher $\mathrm{a}_{\mathrm{w}}$ tended to have lower $\mathrm{b}^{*}$ (i.e., low yellowness). In addition, greater ash content in meat was associated with lower $b^{*}(P<0.001)$.

The intervals of the mean $L^{*}(40.1-44.8)$ and $a^{*}(9.68-12.80)$ observed across breed $\times$ production systems on the third day of storage
(Fig. 3) were below and above, respectively, the values of $\mathrm{L}^{*}$ (46.13-49.47) and a* (8.24-9.85) reported by Sañudo et al. (1997) for lamb meat from Churra, Castellana, Manchega and Awassi breeds. The $a^{*}$ range found in this study was closer to the values 10.39-13.89 measured by Bressan et al. (2001) in lamb meat of Santa Inês and Bergamácia breeds. The mean values of $b *(11.30-13.0)$ were well above those encountered by Bressan et al. (2001) of 6.73-8.15, and by Sañudo et al. (1997) of $8.81-10.75$. Vieira Da Silva et al. (2009) pointed out that many factors determine meat colour, being the most important ones the type of feed, age, weight at slaughter and the storage conditions of meat. Calnan et al. (2016) went further, postulating that production factors are far more important than muscle traits in determining lamb meat colour. In this study, cold carcass weight, $\mathrm{pH}_{24}$, moisture, fat and ash contents were the intrinsic factors with the greatest impact on lamb meat colour.

\subsection{Evolution of lipid oxidation and cooking loss during storage and their relation with the intrinsic properties of meat}

The level of lipid peroxidation in lamb meat, as measured by TBARs, increased during cold storage $(P<0.001$ for Day; Table 2). The lipid oxidation of lamb meat increased linearly with time for all the breed $\times$ production systems (Fig. 4), although the highest TBARs levels were observed in meat from intensive INRA401 and Castellana farms, 
Table 1

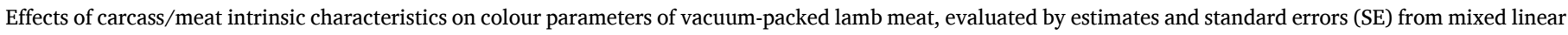
models. Significance of sources of variation is indicated by P-values of F test.

\begin{tabular}{|c|c|c|c|c|c|c|c|}
\hline \multirow{2}{*}{ Model } & \multirow{2}{*}{ Source of variation } & \multicolumn{2}{|c|}{$L^{*}$} & \multicolumn{2}{|c|}{$a^{*}$} & \multicolumn{2}{|c|}{$b^{*}$} \\
\hline & & Estimate (SE) ${ }^{1}$ & P-value (F) & Estimate (SE) ${ }^{1}$ & P-value (F) & Estimate (SE) ${ }^{1}$ & P-value (F) \\
\hline \multirow[t]{3}{*}{ CCW } & Intercept & $48.87(1.099)^{*}$ & $<0.0001$ & $8.280(0.729)^{*}$ & $<0.0001$ & $11.57(0.456)^{*}$ & $<0.0001$ \\
\hline & Day & $0.408(0.079)^{*}$ & $<0.0001$ & $0.853(0.059)^{*}$ & $<0.0001$ & $0.765(0.055)^{*}$ & $<0.0001$ \\
\hline & CCW & $-0.236(0.042)^{*}$ & $<0.0001$ & $0.142(0.028)^{*}$ & $<0.0001$ & $-0.003(0.024)$ & 0.906 \\
\hline \multirow[t]{3}{*}{$\mathrm{pH}_{24}$} & Intercept & $32.62(5.482)^{*}$ & $<0.0001$ & $18.01(3.640)^{*}$ & $<0.0001$ & $10.58(3.489)^{*}$ & $<0.0001$ \\
\hline & Day & $0.409(0.080)^{*}$ & $<0.0001$ & $0.852(0.059)^{*}$ & $<0.0001$ & $0.765(0.055)^{*}$ & $<0.0001$ \\
\hline & $\mathrm{pH}_{24}$ & $1.854(0.955)^{*}$ & 0.050 & $-1.320(0.636)^{*}$ & 0.038 & $0.166(0.614)$ & 0.788 \\
\hline \multirow[t]{4}{*}{$a_{w 24}$} & Intercept & 99.87 (56.94) & $<0.0001$ & $56.51(37.73)$ & $<0.0001$ & $175.6(36.31)^{*}$ & $<0.0001$ \\
\hline & Day & $0.415(0.087)^{*}$ & $<0.0001$ & $0.950(0.063)^{*}$ & $<0.0001$ & $0.815(0.060)^{*}$ & $<0.0001$ \\
\hline & $\mathrm{aw}_{24}$ & $-58.19(57.37)$ & 0.311 & $-45.85(38.01)$ & 0.228 & $-165.5(36.58)^{*}$ & $<0.0001$ \\
\hline & Intercept & $-14.04(8.867)$ & $<0.0001$ & $45.75(5.943)^{*}$ & $<0.0001$ & $14.50(5.847)^{*}$ & $<0.0001$ \\
\hline \multirow[t]{3}{*}{ Moisture (\%) } & Day & $0.409(0.080)^{*}$ & $<0.0001$ & $0.853(0.059)^{*}$ & $<0.0001$ & $0.765(0.055)^{*}$ & $<0.0001$ \\
\hline & Moisture & $0.752(0.116)^{*}$ & $<0.0001$ & $-0.463(0.078)^{*}$ & $<0.0001$ & $-0.039(0.076)$ & 0.610 \\
\hline & Intercept & $43.84(0.811)^{*}$ & $<0.0001$ & $9.725(0.493)^{*}$ & $<0.0001$ & $11.39(0.298)^{*}$ & $<0.0001$ \\
\hline \multirow[t]{3}{*}{ Fat $(\% \mathrm{db})$} & Day & $0.409(0.079)^{*}$ & $<0.0001$ & $0.852(0.059)^{*}$ & $<0.0001$ & $0.765(0.055)^{*}$ & $<0.0001$ \\
\hline & Fat & $-0.103(0.042)^{*}$ & 0.014 & $0.118(0.027)^{*}$ & $<0.0001$ & $-0.020(0.027)$ & 0.461 \\
\hline & Intercept & $44.58(3.475)^{*}$ & $<0.0001$ & $19.19(2.241)^{*}$ & $<0.0001$ & $15.53(2.183)^{*}$ & $<0.0001$ \\
\hline \multirow[t]{3}{*}{ Protein $(\% \mathrm{db})$} & Day & $0.409(0.080)^{*}$ & $<0.0001$ & $0.852(0.059) *$ & $<0.0001$ & $0.765(0.055)^{*}$ & $<0.0001$ \\
\hline & Protein & $-0.017(0.039)$ & 0.672 & $-0.100(0.025)^{*}$ & $<.0001$ & $-0.046(0.025)$ & 0.066 \\
\hline & Intercept & $39.72(1.521)^{*}$ & $<0.0001$ & $16.53(0.959)^{*}$ & $<0.0001$ & $15.08(0.839)^{*}$ & $<0.0001$ \\
\hline \multirow[t]{2}{*}{ Ashes (\% db) } & Day & $0.409(0.080)^{*}$ & $<0.0001$ & $0.853(0.059)^{*}$ & $<0.0001$ & $0.766(0.055)^{*}$ & $<0.0001$ \\
\hline & Ashes & $0.686(0.257)^{*}$ & 0.008 & $-1.204(0.156)^{*}$ & $<0.0001$ & $-0.709(0.160)^{*}$ & $<0.0001$ \\
\hline
\end{tabular}

(1) Asterisk indicates significance of estimates $(P<0.05)$; db: dry basis.

and the lowest in meat from the extensive TMB farm. The linear increase in TBARs was also reported by Fernandes et al. (2012) in lamb loins during cold storage. As a whole, the production system exerted a clear effect on the extent of lipid oxidation in meat. On the 15th day of storage, the mean TBARs of lamb meat from intensive production systems was significantly higher (mean $=0.839 \mathrm{mg} \mathrm{MDA} / \mathrm{kg} ; 95 \% \mathrm{CI}$ : $0.789-0.889 \mathrm{mg} \mathrm{MDA} / \mathrm{kg}$ ) than that of the semi-extensive production systems (0.396 mg MDA/kg; 95\% CI: $0.352-0.440 \mathrm{mg} \mathrm{MDA} / \mathrm{kg}$ ), which was in turn higher than the mean TBARs of meat from extensively raised lambs (0.299 mg MDA/kg; 95\% CI: 0.270 - $0.328 \mathrm{mg} \mathrm{MDA} / \mathrm{kg}$ ).

As explained in Domínguez et al. (2019), the fat content and fatty acids composition have implications on the lipid oxidation processes, being the unsaturation of fat even more important that the fat content in oxidative susceptibility. Tocopherol is one of the most important antioxidants present in meat, and hence, the lower rate of TBARs in extensively-raised lambs could be linked to the fact that animals fed with high amounts of grass have greater oxidative stability due to a higher intake of tocopherol (Domínguez et al., 2019).

The mixed effects models suggest that lipid oxidation in lamb meat was driven or affected by all the intrinsic properties evaluated, except $\mathrm{pH}_{24}$, namely CCW $(P=0.016)$, aw $(P<0.001)$, moisture $(P<0.001)$, IMF $(P<0.001)$, protein $(P=0.035)$ and ash content $(P<0.001)$. Meat from heavier carcasses tended to undergo greater lipid oxidation. For both intrinsic properties related to water content, $\mathrm{a}_{\mathrm{w}}$ and moisture, the trend was the same: lamb meat with higher levels of free water and moisture, presented a slower lipid oxidation. Meat of higher IMF content, and therefore lower protein and ash contents, tended to undergo greater lipid peroxidation. There is evidence that unsaturated fatty acids are more prone to oxidation (Faustman et al., 2010). Although the fatty acid profile has not been studied in this work, sheep meat has been said to be less susceptible to lipid oxidation than beef (Ellis and Bertol, 2001), because it is particularly rich in saturated fatty acids and has a low polyunsaturated content (Sinclair, 2007). Cooking loss is another important quality attribute because it is linked to the yield of meat after cooking and juiciness (Pateiro et al., 2013). During cold storage, the cooking loss of lamb meat significantly increased $(P<0.001$ for Day in Table 2), although the loss in water holding capacity tended to occur slowly between the 3rd and 9th day of storage, and slightly more abrupt between the 9th and the 15th day (Fig. 4). In addition, the change in water holding capacity of lamb meat was variable between breed $\times$ production systems. For reference, averaging over the three sampling time points (results not shown), meat from Biellese and Sambucana lambs presented the lowest mean cooking losses of $15.1 \%$ (95\% CI: $14.1-16.2 \%$ ) and $16.7 \%$ (95\% CI: $15.8-17.6 \%$ ), respectively; whereas the meat from TMB, semi-intensive Gallega and semi-intensive Castellana farms suffered the greatest cooking losses at mean values of $22.2 \%(21.3-23.1 \%), 22.6 \%(21.3-24.0 \%)$ and $22.8 \%$ (21.6-24.0), respectively. At the end of the storage period, meat from the other breed $\times$ production systems presented mean cooking losses between $18.6 \%$ and $20.9 \%$. Overall, no discernible effect of production system on cooking loss of lamb meat was found. Similar outcomes were observed by Ekiz et al. (2012b) in Kivircik lambs reared under different production systems.

According to the mixed models, cooking loss was affected by CCW $(P=0.050)$, moisture $(P=0.048)$ and ash content $(P<0.001)$ (Table 2). Meat from heavier carcasses underwent a lower or slower cooking loss during storage; in other words, at the end of cold storage, these meats would retain more water than the meat from lighter lambs. Camacho et al. (2017) and Abdullah and Qudsieh (2009) pointed out that the lower cooking loss in heavier carcasses could be due to the greater fatness of these lambs. In fact, Santos-Silva et al. (2002) noticed that a greater IMF content in meat leads to a higher water holding capacity. The inverse relationship between animal fatness and cooking loss was earlier pointed out by Sañudo et al. (1997), who explained that the fat present in meat does not only act as a barrier against cooking loss, but also produces more succulent meat. Moreover, Pardi et al. (2001) argued that the greater water holding capacity of lamb meat may stem from greater quantities of fat in the tissues, because possibly, apart from moisture, part of meat fat is also lost with thermal processing. Nonetheless, in our study, despite CCW and cooking loss were found to be inversely correlated, the IMF content of meat was not found to be determinant in cooking loss $(P=0.247)$. Furthermore, the statistical analysis suggested that lamb meat with higher initial moisture content or lower ash content suffered greater losses of water during cooking. Thus, it is expected that this meat has a lower water holding capacity when cooked, and therefore, is less succulent. 
Table 2

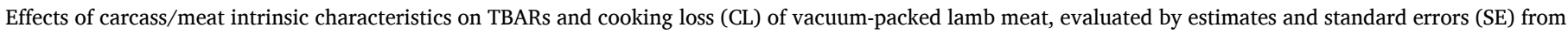
mixed linear models. Significance of sources of variation is indicated by $P$-values of $\mathrm{F}$ test.

\begin{tabular}{|c|c|c|c|c|c|}
\hline \multirow{2}{*}{ Model } & \multirow{2}{*}{ Source of variation } & \multicolumn{2}{|c|}{$\log (\text { TBARs })^{1}$} & \multicolumn{2}{|c|}{$\log (C L)^{1}$} \\
\hline & & Estimate (SE) $)^{2}$ & $P$-value (F) & Estimate (SE) $)^{2}$ & $P$-value (F) \\
\hline \multirow[t]{3}{*}{ CCW } & Intercept & $-6.300(0.485)^{*}$ & $<0.0001$ & $2.843(0.074)^{*}$ & $<0.0001$ \\
\hline & Day & $1.511(0.065)^{*}$ & $<0.0001$ & $0.071(0.009)^{*}$ & $<0.0001$ \\
\hline & CCW & $0.056(0.023)^{*}$ & 0.016 & $-0.005(0.002)$ & 0.050 \\
\hline \multirow[t]{3}{*}{$\mathrm{pH}_{24}$} & Intercept & $-2.726(2.655)$ & $<0.0001$ & $3.037(0.398)^{*}$ & $<0.0001$ \\
\hline & Day & $1.512(0.065)^{*}$ & $<0.0001$ & $0.072(0.009)^{*}$ & $<0.0001$ \\
\hline & $\mathrm{pH}_{24}$ & $-0.474(0.465)$ & 0.309 & $-0.047(0.070)$ & 0.494 \\
\hline \multirow[t]{4}{*}{$a_{w 24}$} & Intercept & $159.2(25.25)^{*}$ & $<0.0001$ & $25.90(3.953)^{*}$ & $<0.0001$ \\
\hline & Day & $1.511(0.065)^{*}$ & $<0.0001$ & $0.060(0.010)^{*}$ & $<0.0001$ \\
\hline & $\mathrm{aw}_{24}$ & $-165.9(25.44)^{*}$ & $<0.0001$ & $-23.21(20.98)^{*}$ & 0.735 \\
\hline & Intercept & $18.64(4.523)^{*}$ & $<0.0001$ & $1.618(0.675)^{*}$ & $<0.0001$ \\
\hline \multirow[t]{3}{*}{ Moisture (\%) } & Day & $1.511(0.065)^{*}$ & $<0.0001$ & $0.072(0.009)^{*}$ & $<0.0001$ \\
\hline & Moisture & $-0.318(0.059)^{*}$ & $<0.0001$ & $0.015(0.009)$ & 0.048 \\
\hline & Intercept & $-6.026(0.357)^{*}$ & $<0.0001$ & $2.792(0.057)^{*}$ & $<0.0001$ \\
\hline \multirow[t]{3}{*}{ Fat $(\% \mathrm{db})$} & Day & $1.511(0.065)^{*}$ & $<0.0001$ & $0.072(0.009)^{*}$ & $<0.0001$ \\
\hline & Fat & $0.087(0.020)^{*}$ & $<0.0001$ & $-0.004(0.003)$ & 0.247 \\
\hline & Intercept & $-1.924(1.677)$ & $<0.0001$ & $2.491(0.250)^{*}$ & $<0.0001$ \\
\hline \multirow[t]{3}{*}{ Protein $(\% \mathrm{db})$} & Day & $1.512(0.065)^{*}$ & $<0.0001$ & $0.072(0.009)^{*}$ & $<0.0001$ \\
\hline & Protein & $-0.041(0.019)^{*}$ & 0.035 & $0.003(0.003)$ & 0.258 \\
\hline & Intercept & $-1.828(0.678)^{*}$ & $<0.0001$ & $3.058(0.108)^{*}$ & $<0.0001$ \\
\hline \multirow[t]{2}{*}{ Ashes (\% db) } & Day & $1.511(0.065)^{*}$ & $<0.0001$ & $0.072(0.009)^{*}$ & $<0.0001$ \\
\hline & Ashes & $-0.706(0.118)^{*}$ & $<0.0001$ & $-0.058(0.019)^{*}$ & 0.002 \\
\hline
\end{tabular}

(1) Response variable was log-transformed for model fitting.

(2) Asterisk indicates significance of estimates $(P<0.05)$.

\subsection{Evolution of Warner-Bratzler texture attributes during storage and their relation with the intrinsic properties of meat}

The hardness parameters - slope, work and shear force - of lamb meat were found to decline progressively during storage, more abruptly at the beginning (from the 3rd to the 9th day) and more asymptotically afterwards (from the 9th to the 15th day) (Fig. 5). For that reason, in the mixed models the linear and quadratic term of storage time (Day and Day ${ }^{2}$ ) were significant in all cases (Table 3 ), suggesting in this way the non-linear decay of the evolution of the tenderness attributes in time.

As occurred with the other quality attributes, a high variability in meat tenderness between breed $\times$ production systems was observed (Fig. 5). Meat from semi-extensively raised Castellana, intensivelyraised INRA401, and semi-extensively raised Gallega Spanish lambs presented the lowest values of WB slope - in the order of 4.96-6.30 N/s on the 15th day of storage; whereas lamb meat from the Portuguese breeds, BEDM and CGB, presented the highest values (7.43-7.65 N/s at the end of storage). A similar breed-specific trend was observed in the other texture attributes, work and shear force, reaching meat from intensive INRA401 and semi-extensive Castellana the lowest values by the end of storage $\left(80.9-82.0 \mathrm{~N} . \mathrm{mm}\right.$ and $16.0-20.5 \mathrm{~N} / \mathrm{cm}^{2}$, respectively) and meat from semi-intensive CGB the highest ones (148.5 N.mm and $28.6 \mathrm{~N} / \mathrm{cm}^{2}$, respectively).

In terms of production system, on the 3rd and 9th day of storage, the meat from intensively-reared lambs presented significantly lower WB slope values $(8.07 \mathrm{~N} / \mathrm{s}$; 95\% CI: 7.47-8.69 N/s and $6.19 \mathrm{~N} / \mathrm{s} ; 95 \% \mathrm{CI}$ : $5.58-6.80 \mathrm{~N} / \mathrm{s}$, respectively) than the meat from both extensively-reared (9.35 N/s; 95\% CI: 8.96-9.75 N/s and 7.35 N/s; 95\% CI: 6.95-7.75 N/s) and semi-extensively reared lambs $(9.76 \mathrm{~N} / \mathrm{s} ; 95 \% \mathrm{CI}: 9.23-10.29 \mathrm{~N} / \mathrm{s}$ and $7.38 \mathrm{~N} / \mathrm{s}$; 95\% CI: 6.85-7.92 N/s). Nonetheless, by the 15 th day of storage, the meat from semi-extensively and extensively-raised lambs had reached the same level of tenderisation as the meat from intensively-raised lambs, as deduced by the non-significant differences in WB slope between production systems $(6.16 \mathrm{~N} / \mathrm{s} ; 95 \% \mathrm{CI}$ : 5.56-6.77 N/s for extensive; $6.62 \mathrm{~N} / \mathrm{s}$; $95 \% \mathrm{CI}$ : $6.21-7.01 \mathrm{~N} / \mathrm{s}$ for semiextensive; and $6.70 \mathrm{~N} / \mathrm{s}$; $95 \% \mathrm{CI}$ : $6.17-7.24 \mathrm{~N} / \mathrm{s}$ for intensive). The same trend was observed for the other WB parameters, work and shear force. This is, on the 3rd and 9th day of storage, meat from intensively-raised lambs were significantly more tender (lower shear force; $30.5 \mathrm{~N} / \mathrm{cm}^{2}$;
95\% CI: $27.7-33.2 \mathrm{~N} / \mathrm{cm}^{2}$ and $21.6 \mathrm{~N} / \mathrm{cm}^{2}$; $95 \% \mathrm{CI}: 18.8-24.3 \mathrm{~N} / \mathrm{cm}^{2}$, respectively) than that of extensively-reared $\left(35.6 \mathrm{~N} / \mathrm{cm}^{2} ; 95 \% \mathrm{CI}\right.$ : 33.9-37.4 N/cm ${ }^{2}$ and $\left.25.5 \mathrm{~N} / \mathrm{cm}^{2} ; 95 \% \mathrm{CI}: 23.6-27.2 \mathrm{~N} / \mathrm{cm}^{2}\right)$ and semiextensively reared lambs $\left(37.4 \mathrm{~N} / \mathrm{cm}^{2}\right.$; $95 \%$ CI: $35.0-39.9 \mathrm{~N} / \mathrm{cm}^{2}$ and $27.4 \mathrm{~N} / \mathrm{cm}^{2}$; $95 \%$ CI: $25.1-29.9 \mathrm{~N} / \mathrm{cm}^{2}$ ). These differences between production systems could be related to the different intake of nutrients or exercise requirement to find food, which later reflects into differences in carcass fatness (De Brito et al., 2017). Nonetheless, on the last day of storage, mean shear force values of the three production systems did not statistically differ one from the other $\left(22.1 \mathrm{~N} / \mathrm{cm}^{2} ; 95 \% \mathrm{CI}\right.$ : $19.3-24.8 \mathrm{~N} / \mathrm{cm}^{2}$ for intensive; $23.4 \mathrm{~N} / \mathrm{cm}^{2}$; $95 \%$ CI: $21.6-25.3 \mathrm{~N} / \mathrm{cm}^{2}$ for extensive; and $24.4 \mathrm{~N} / \mathrm{cm}^{2}$; $95 \%$ CI: $22.1-26.9 \mathrm{~N} / \mathrm{cm}^{2}$ for semi-extensive). These values suggest that meat was very tender, most likely due to the young age of lambs at slaughter. In addition, these results were very acceptable since Warner-Bratzler shear force values greater than $54 \mathrm{~N} / \mathrm{cm}^{2}$ are often considered tough and rejectable by consumers (Webb et al., 2005).

After analyzing the effects of the carcass/meat intrinsic properties on the texture attributes (Table 3), it was evident that most of the intrinsic properties evaluated determined the instrumental texture of the lamb meat within the breed $\times$ production systems; namely, CCW $(P=0.014$ for slope and $P=0.027$ for shear force), $\mathrm{a}_{\mathrm{w}}(P<0.001$ for slope and $P=0.036$ for shear force), moisture $(P=0.013$ for slope and shear force), IMF ( $P=0.004$ for slope, $P=0.050$ for work and $P=0.001$ for shear force) and ash content $(P<0.001$ for slope and $P=0.002$ for shear force). According to our results, neither $\mathrm{pH}_{24}$ nor protein content exerted any influence on lamb meat tenderness.

The carcasses with higher cold weight presented lower slope and shear force, thus yielding tenderer meat. The relationship between carcass weight and meat tenderness was also modulated by the IMF content of the meat (Komprda et al., 2012). Meat with higher IMF underwent a more rapid tenderization than meat with lower IMF, as implied by the significant negative interaction term Fat $\times$ Day (Table 3). The relationship of fat content and CCW with the WB parameters evidences that heavier animals at the same slaughter age had a higher fattening state. Our results are in agreement with those encountered by Koohmaraie et al. (1995) and Shackelford et al. (1997), who found that carcasses with a lower percentage of lean meat (higher proportion of fat) were at the same time more tender and succulent meat. 
Table 3

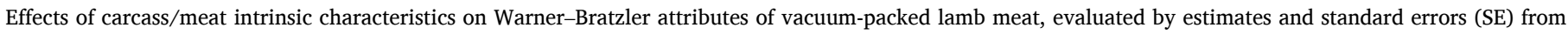
mixed linear models. Significance of sources of variation is indicated by $P$-values of $\mathrm{F}$ test.

\begin{tabular}{|c|c|c|c|c|c|c|c|}
\hline \multirow{2}{*}{ Model } & \multirow{2}{*}{ Source of variation } & \multicolumn{2}{|c|}{$\log (\text { Slope })^{1}$} & \multicolumn{2}{|c|}{$\log (\text { Work })^{1}$} & \multicolumn{2}{|c|}{$\log (\text { Force })^{1}$} \\
\hline & & Estimate $(\mathrm{SE})^{2}$ & $P$-value (F) & Estimate $(\mathrm{SE})^{2}$ & $P$-value (F) & Estimate $(\mathrm{SE})^{2}$ & $P$-value (F) \\
\hline \multirow[t]{4}{*}{ CCW } & Intercept & $3.116(1.156)$ & $<0.0001$ & 31.24 (1.529)* & $<0.0001$ & $17.32(1.303)^{*}$ & $<0.0001$ \\
\hline & CCW & $-0.011(0.004) *$ & 0.014 & $0.001(0.006)$ & 0.892 & $-0.012(0.005)^{*}$ & 0.027 \\
\hline & Day & $-0.414(0.078) *$ & $<0.0001$ & $-0.720(0.103) *$ & $<0.0001$ & $-0.574(0.087)^{*}$ & $<0.0001$ \\
\hline & Day $^{2}$ & $0.064(0.019)^{*}$ & 0.001 & $0.131(0.025)^{*}$ & $<0.0001$ & $0.097(0.022)^{*}$ & $<0.0001$ \\
\hline \multirow[t]{4}{*}{$\mathrm{pH}_{24}$} & Intercept & $5.550(4.890)$ & $<0.0001$ & $37.36(6.440)^{*}$ & $<0.0001$ & $24.07(5.600)^{*}$ & $<0.0001$ \\
\hline & $\mathrm{pH}_{24}$ & $-0.074(0.084)$ & 0.378 & $-0.095(0.112)$ & 0.396 & $-0.146(0.097)$ & 0.132 \\
\hline & Day & $-0.414(0.078)^{*}$ & $<0.0001$ & $-0.720(0.103)^{*}$ & $<0.0001$ & $-0.574(0.087)$ & $<0.0001$ \\
\hline & Day $^{2}$ & $0.064(0.019) *$ & $<0.0001$ & $0.131(0.025)^{*}$ & $<0.0001$ & $0.097(0.022)$ & $<0.0001$ \\
\hline \multirow{5}{*}{$\mathrm{a}_{\mathrm{w} 24}$} & Intercept & $-183.00(40.2)$ & $<0.0001$ & $-54.15(65.68)$ & $<0.0001$ & $-103.4(56.98)$ & $<0.0001$ \\
\hline & $\mathrm{aw}_{24}$ & $18.57(4.837)$ & $<0.0001$ & $8.682(6.617)$ & 0.186 & $12.01(5.741)^{*}$ & 0.036 \\
\hline & Day & $-0.414(0.079)$ & $<0.0001$ & $-0.720(0.103)^{*}$ & $<0.0001$ & $-0.574(0.088)$ & $<0.0001$ \\
\hline & Day $^{2}$ & $0.064(0.019)$ & $<0.0001$ & $0.131(0.025)^{*}$ & $<0.0001$ & $0.097(0.022)$ & $<0.0001$ \\
\hline & Intercept & $-20.32(8.680)^{*}$ & $<0.0001$ & $25.42(11.68)^{*}$ & $<0.0001$ & $-9.320(10.06)$ & $<0.0001$ \\
\hline \multirow{4}{*}{ Moisture (\%) } & Moisture & $0.029(0.011)^{*}$ & 0.013 & $0.008(0.015)$ & 0.573 & $0.033(0.013)$ & 0.013 \\
\hline & Day & $-0.414(0.079)^{*}$ & $<0.0001$ & $-0.720(0.103)^{*}$ & $<0.0001$ & $-0.574(0.087)$ & $<0.0001$ \\
\hline & Day $^{2}$ & $0.064(0.019)^{*}$ & 0.001 & $0.131(0.025)^{*}$ & $<0.0001$ & $0.097(0.022)$ & $<0.0001$ \\
\hline & Intercept & $1.330(1.000)$ & $<0.0001$ & $32.00(1.200)^{*}$ & $<0.0001$ & $15.74(1.100)^{*}$ & $<0.0001$ \\
\hline \multirow{4}{*}{$\mathrm{Fat}^{3}(\% \mathrm{db})$} & Fat $\times$ Day & $-0.005(0.001)^{*}$ & 0.004 & $-0.004(0.002)$ & 0.050 & $-0.006(0.001)^{*}$ & 0.001 \\
\hline & Day & $-0.378(0.079)^{*}$ & 0.001 & $-0.691(0.104)^{*}$ & $<0.0001$ & $-0.529(0.088)^{*}$ & $<0.0001$ \\
\hline & Day $^{2}$ & $0.064(0.019) *$ & 0.011 & $0.131(0.025)^{*}$ & $<0.0001$ & $0.097(0.021)^{*}$ & $<0.0001$ \\
\hline & Intercept & $-0.560(0.313)$ & $<0.0001$ & 28.43 (4.130)* & $<0.0001$ & $11.38(3.610)^{*}$ & $<0.0001$ \\
\hline \multirow{4}{*}{ Protein $(\% \mathrm{db})$} & Protein & $0.002(0.003)$ & 0.520 & $0.004(0.005)$ & 0.368 & $0.005(0.004)$ & 0.204 \\
\hline & Day & $-0.414(0.079)^{*}$ & $<0.0001$ & $-0.720(0.103)$ & $<0.0001$ & $-0.574(0.088)$ & $<0.0001$ \\
\hline & Day $^{2}$ & $0.064(0.019)^{*}$ & 0.001 & $0.131(0.025)$ & $<0.0001$ & $0.097(0.021)$ & $<0.0001$ \\
\hline & Intercept & $-3.370(1.470)^{*}$ & $<0.0001$ & $29.55(1.920)^{*}$ & $<0.0001$ & $11.65(1.690)^{*}$ & $<0.0001$ \\
\hline \multirow{3}{*}{ Ashes (\% db) } & Ashes & $0.094(0.022)^{*}$ & $<0.0001$ & $0.049(0.030)$ & 0.103 & $0.082(0.257)^{*}$ & 0.002 \\
\hline & Day & $-0.414(0.078)^{*}$ & $<0.0001$ & $-0.720(0.103)^{*}$ & $<0.0001$ & $-0.574(0.088)^{*}$ & $<0.0001$ \\
\hline & Day $^{2}$ & $0.064(0.019) *$ & 0.001 & $0.131(0.025)^{*}$ & $<0.0001$ & $0.097(0.022)^{*}$ & $<0.0001$ \\
\hline
\end{tabular}

(1) Response variable was log-transformed for model fitting. Data from Italian and German breeds not included in the analysis.

(2) Asterisk indicates significance of estimates $(P<0.05)$.

(3) Fat was significant only in interaction with Day for the three models.

Meat with higher moisture, free water or higher ash content required more shear force, so they would be perceived as less tender. Interestingly, ash content was the only intrinsic property that exerted an effect on all of the quality attributes of meat, except for WB work. Ashes reflect the contents of Fe, $\mathrm{Zn}, \mathrm{P}, \mathrm{K}, \mathrm{Mg}$, and Se that are mainly provided by lamb meat (Ramírez-Retamal and Morales, 2014). Osorio et al. (2007) stated that different minerals can be associated with the quality of meat given their influence on attributes such as colour, oxidation and tenderness. This was corroborated in our study.

In terms of the degree of tenderness of the lamb meat from the different European farms used in this experiment, the shear force mean values ranged between 24.5 and $40.7 \mathrm{~N} / \mathrm{cm}^{2}$ on the $3 \mathrm{rd}$ day, $15.8-31.7 \mathrm{~N} / \mathrm{cm}^{2}$ on the 9 th day, and $15.9-28.6 \mathrm{~N} / \mathrm{cm}^{2}$ on the 15 th day of cold storage. Shija et al. (2013) estimated that shear force below $40 \mathrm{~N} / \mathrm{cm}^{2}$ equates an acceptable level of tenderness of the meat in the Australian market, whereas Hopkins et al. (2006) indicated that sheep meat with shear force values lower than $48.0 \mathrm{~N} / \mathrm{cm}^{2}$ are considered as tender by the consumers. Furthermore, Aksoy and Ulutas (2016) stated meat having shear force higher than $54 \mathrm{~N} / \mathrm{cm}^{2}$ can be considered as tough. Taking into consideration these shear force cut-off values, it can be stated that the lamb meat from the studied breed $\times$ production systems are of high edible quality.

\section{Conclusion}

Apart from the effect of storage time, the intrinsic properties of carcass/meat were found to regulate, to different extent, the changes in quality attributes. Within farms, ultimate $\mathrm{pH}$ only regulated $\mathrm{L}^{*}$ and $\mathrm{a*}$, being lamb meat of lower $\mathrm{pH}$ of a lighter bright red colour. Meat of higher moisture content was found to have higher luminosity, lower redness, lower tenderness, higher cooking loss, while undergoing a slower lipid oxidation. Among the intrinsic properties studied, cold carcass weight and intramuscular fat content had an impact on all of the quality attributes. Heavier lamb carcasses or meat of higher intramuscular fat were associated to darker meat, higher redness, greater lipid oxidation and lower slope and force. In addition, within breed $\times$ production system, heavier animals produced meat of lower cooking loss. Meat of higher protein content tended to be lower in redness and to undergo a slower lipid oxidation. The quality attributes that turned out to be the least sensitive to intrinsic characteristics were shear work and $b^{*}$. Shear work was only modulated by intramuscular fat content in an inverse relationship, whereas $b *$ was positively correlated with water activity. Ash content of meat was the only intrinsic property that heavily affected most of the quality attributes studied, except for shear work. Within farms, meat of higher ash content presented higher luminosity and lower redness, yellowness, TBARS, cooking loss and tenderness.

Production system affected cold carcass weight, producing intensive systems heavier carcasses $(21.4 \mathrm{Kg}$ ) than those raised in semi-extensive $(14.9 \mathrm{Kg})$ and extensive systems $(13.8 \mathrm{Kg})$ systems. Lipid oxidation and tenderness of meat were strongly influenced by the production system. On the 15th day of storage, the mean TBARs of lamb meat from intensive production systems were higher than that from semi-extensive and extensive systems. Despite the high variability found in the tenderness attributes between breed $\times$ production systems, the lamb meat was of good tenderness quality. On the 3rd and 9th day, meat from intensivelyreared lambs was more tender than the meat from extensively and semiextensively reared lambs; however on the 15th day of storage, the meat from semi-extensively and extensively-raised lambs had reached the same level of tenderisation as that of intensively-raised lambs.

The elucidation of the impact of intrinsic properties on the lamb meat quality attributes during storage can help breeders and producers to modify current flock management, feeding strategies and preslaughter and slaughter practices that drive important intrinsic properties such as weight at slaughter, intramuscular fat content and ultimate 
$\mathrm{pH}$, in order to meet consumers' demands.

\section{CRediT authorship contribution statement}

Ursula Gonzales-Barron: Conceptualization, Formal analysis, Funding acquisition, Investigation, Methodology, Project administration, Resources, Software, Visualization, Supervision, Writing - original draft, Writing - review \& editing. Gisela Santos-Rodrigues: Investigation, Methodology, Visualization. Roberto Bermúdez Piedra: Investigation, Methodology, Supervision, Validation, Visualization. Sara Coelho-Fernandes: Investigation, Methodology, Visualization. Koldo Osoro: Funding acquisition, Project administration, Resources. Rafael Celaya: Investigation, Methodology, Supervision, Validation, Visualization, Writing - review \& editing. Raimundo Serrão Maurício: Investigation, Visualization. Jaime Pires: Investigation, Visualization. Anna Tolsdorf: Investigation, Supervision, Validation, Visualization. Andreas Geß: Investigation, Methodology, Supervision, Validation, Visualization, Resources. Francesco Chiesa: Investigation, Methodology, Supervision, Validation, Visualization. Mirian Pateiro: Investigation, Methodology, Visualization. Alberto Brugiapaglia: Investigation, Methodology, Supervision, Validation, Visualization. Raúl Bodas: Funding acquisition, Project administration, Resources, Supervision, Visualization, Writing - review \& editing. Mario Baratta: Funding acquisition, Project administration, Resources, Visualization, Supervision, Writing - review \& editing. José M. Lorenzo: Conceptualization, Funding acquisition, Investigation, Methodology, Project administration, Resources, Supervision, Visualization, Writing - review \& editing. Vasco A.P. Cadavez: Conceptualization, Formal analysis, Funding acquisition, Investigation, Methodology, Project administration, Resources, Software, Supervision, Visualization, Writing - original draft, Writing - review \& editing.

\section{Declaration of Competing Interest}

The authors declare that they have no known competing financial interests or personal relationships that could have appeared to influence the work reported in this paper.

\section{Acknowledgments}

The authors are grateful to EU ERA-NET programme and the Portuguese Foundation for Science and Technology (FCT) for funding the project "EcoLamb-Holistic Production to Reduce the Ecological Footprint of Meat (SusAn/0002/2016). CIMO authors are grateful to FCT and FEDER under Programme PT2020 for financial support to CIMO (UIDB/00690/2020). Dr. Gonzales-Barron acknowledges the national funding by FCT, P.I., through the Institutional Scientific Employment Programme contract. José M. Lorenzo is member of the HealthyMeat network, funded by CYTED (ref. 119RT0568).

\section{References}

Abdullah, A.Y., Qudsieh, R.I., 2009. Effect of slaughter weight and aging time on the quality of meat from Awassi ram lambs. Meat Sci. 82, 309-316. https://doi.org/ 10.1016/j.meatsci.2009.01.027.

Aksoy, Y., Ulutas, Z., 2016. Meat production traits of local Karayaka sheep in Turkey I. the meat quality characteristic of lambs. Ital. J. Food Sci. 28, 131-138. https://doi. org/10.14674/1120-1770/ijfs.v465.

AOCS, 2005. AOCS Official Procedure Am5-04. Rapid Determination of oil/fat Utilizing High Temperature Solvent Extraction. Sampling and Analysis of Vegetable Oil Source Materials AOCS. American Oil Chemists Society, Urbana, IL, USA.

Ball, A.J., Thompson, J.M., Alston, C.L., Blakely, A.R., Hinch, G.N., 1998. Changes in maintenance energy requirements of mature sheep fed at different levels of feed intake at maintenance, during weight loss and realimentation. Livest. Prod. Sci. 53, 191-204. https://doi.org/10.1016/S0301-6226(97)00160-7.

Beriain, M.J., 1998. Calidad de la carne ovina. In: Buxadé, C. (Ed.), Ovino De Carne: Aspectos Claves. Mundi-Prensa, Madrid, Spain, pp. 401-418.

Bernués, A., Ruiz, R., Olaizola, A., Villalba, D., Casasús, I., 2011. Sustainability of pasture-based livestock farming systems in the European Mediterranean context: synergies and trade-offs. Livest. Sci. 139, 44-57. https://doi.org/10.1016/j. livsci.2011.03.018.

Borton, R.J., Loerch, S.C., McClure, K.E., Wulf, D.M., 2005. Comparison of characteristics of lambs fed concentrate or grazed on ryegrass to traditional or heavy slaughter weights. I. Production, carcass, and organoleptic characteristics1. J. Anim. Sci. 83, 679-685. https://doi.org/10.2527/2005.833679x.

Bressan, M.C., Prado, O.V., Pérez, J.R.O., Lemos, A.Lda S.C., Bonagurio, S., 2001. Efeito do peso ao abate de cordeiros Santa Inês e Bergamácia sobre as características físicoquímicas da carne. Ciência e Tecnol. Aliment. 21, 293-303. https://doi.org/ 10.1590/s0101-20612001000300008.

Calnan, H., Jacob, R.H., Pethick, D.W., Gardner, G.E., 2016. Production factors influence fresh lamb longissimus colour more than muscle traits such as myoglobin concentration and pH. Meat Sci. 119, 41-50. https://doi.org/10.1016/j. meatsci.2016.04.009.

Camacho, A., Torres, A., Capote, J., Mata, J., Viera, J., Bermejo, L.A., Argüello, A., 2017. Meat quality of lambs (hair and wool) slaughtered at different live weights. J. Appl. Anim. Res. 45, 400-408. https://doi.org/10.1080/09712119.2016.1205498.

Carrapiso, A.I., García, C., 2005. Instrumental colour of Iberian ham subcutaneous fat and lean (biceps femoris): influence of crossbreeding and rearing system. Meat Sci. 71, 284-290. https://doi.org/10.1016/j.meatsci.2005.03.024.

Cruz, B.C., Cerqueira, J., Araújo, J.P., Gonzales-Barron, U., Cadavez, V., 2019. Study of Growth Performance of Churra-galega-Bragançana and Bordaleira-de-Entre-Douro-eMinho Lamb breeds., in: XVIII Jornadas Sobre Producción Animal, Zaragoza, España, 7 Y 8 De Mayo De 2019. Asociación Interprofesional Para El Desarrollo Agrario, pp. 66-68.

De Brito, G.F., Ponnampalam, E.N., Hopkins, D.L., 2017. The effect of extensive feeding systems on growth rate, carcass traits, and meat quality of finishing lambs. Compr. Rev. Food Sci. Food Saf. 16, 23-38. https://doi.org/10.1111/1541-4337.12230.

De La Fuente, J., Snchez, M., Prez, C., Lauzurica, S., Vieira, C., Gonzlez De Chvarri, E., Daz, M.T., 2010. Physiological response and carcass and meat quality of suckling lambs in relation to transport time and stocking density during transport by road. Animal 4, 250-258. https://doi.org/10.1017/S1751731109991108.

De-Arriba, R., Sánchez-Andrés, A., 2014. Production and productivity in Eastern and Western European sheep farming: a comparative analysis [WWW Document]. Livest. Res. Rural Dev. URL http://www.lrrd.org/lrrd26/4/arri26066.htm (accessed 7.3.20).

Dhanda, J.S., Taylor, D.G., Murray, P.J., Pegg, R.B., Shand, P.J., 2003. Goat meat production: present status and future possibilities. Asian-Australasian J. Anim. Sci. https://doi.org/10.5713/ajas.2003.1842.

Domínguez, R., Crecente, S., Borrajo, P., Agregán, R., Lorenzo, J.M., 2015. Effect of slaughter age on foal carcass traits and meat quality. Animal 9, 1713-1720. https:// doi.org/10.1017/s1751731115000671.

Domínguez, R., Pateiro, M., Gagaoua, M., Barba, F.J., Zhng, W., Lorenzo, J.M., 2019. A comprehensive review on lipid oxidation in meat and meat products. Antioxidants 8 (10), 429. https://doi.org/10.3390/antiox8100429.

Ekiz, B., Ergul Ekiz, E., Kocak, O., Yalcintan, H., Yilmaz, A., 2012a. Effect of preslaughter management regarding transportation and time in lairage on certain stress parameters, carcass and meat quality characteristics in Kivircik lambs. Meat Sci. 90, 967-976. https://doi.org/10.1016/j.meatsci.2011.11.042.

Ekiz, B., Yilmaz, A., Ozcan, M., Kocak, O., 2012b. Effect of production system on carcass measurements and meat quality of Kivircik lambs. Meat Sci. 90, 465-471. https:// doi.org/10.1016/j.meatsci.2011.09.008.

Ekiz, B., Demirel, G., Yilmaz, A., Ozcan, M., Yalcintan, H., Kocak, O., Altinel, A., 2013. Slaughter characteristics, carcass quality and fatty acid composition of lambs under four different production systems. Small Rumin. Res. 114, 26-34. https://doi.org/ 10.1016/j.smallrumres.2013.05.011.

Ekiz, B., Yilmaz, A., Yalcintan, H., Yakan, A., Kocak, O., Ozcan, M., 2019. The effect of production system and finish weight on carcass and meat quality of Kivircik lambs. Ann. Anim. Sci. 19, 517-538. https://doi.org/10.2478/aoas-2019-0010.

Ellis, M., Bertol, T.M., 2001. Efeitos Do Peso De Abate Sobre a Qualidade De Carne Suína E Da Gordura. in: $2^{\text {a }}$ Conferência Internacional Virtual Sobre Qualidade De Carne Suína. Embrapa Suínos E Aves, concórdia, SC, Brazil, pp. 227-239.

Erasmus, S.W., Muller, M., Hoffman, L.C., 2017. Authentic sheep meat in the European Union: factors influencing and validating its unique meat quality. J. Sci. Food Agric. 97, 1979-1996. https://doi.org/10.1002/jsfa.8180.

Eurostat, 2019. Agriculture, forestry and fishery statistics - 2019 edition - Product Eurostat [WWW Document]. Eur. Comm. (accessed 5.10.20) https://ec.europa. eu/eurostat/web/products-statistical-books/-/KS-FK-19-001.

Faustman, C., Sun, Q., Mancini, R., Suman, S.P., 2010. Myoglobin and lipid oxidation interactions: mechanistic bases and control. Meat Sci. 86, 86-94. https://doi.org/ 10.1016/j.meatsci.2010.04.025.

Fernandes, Rde P.P., Freire, M.Tde A., Guerra, C.C., Carrer, Cda C., Balieiro, J.Cde C., Trindade, M.A., 2012. Physical and chemical stability microbiological and sensory analysis of vacuum packed sheep meat stored under refrigeration. Ciência Rural. Rural 42, 724-729. https://doi.org/10.1590/s0103-84782012000400025.

Gallo, S.B., Arrigoni, M.de B., Lemos, A.Lda S.C., Haguiwara, M.M.H., Bezerra, H.V.A., 2019. Influence of lamb finishing system on animal performance and meat quality. Acta Sci. - Anim. Sci. 41, e44742 https://doi.org/10.4025/actascianimsci. v41i1.44742.

Hopkins, D.L., Hegarty, R.S., Walker, P.J., Pethick, D.W., 2006. Relationship between animal age, intramuscular fat, cooking loss, $\mathrm{pH}$, shear force and eating quality of aged meat from sheep. Aust. J. Exp. Agric. 46, 884. https://doi.org/10.1071/ EA05311.

Islam, S.M.A., Farzana, F., Murshed, H.M., Rahman, S.M.E., 2019. Study on meat quality of native sheep raised in organic and conventional production system. J. Meat Sci. Technol. 7, 1-7. 
ISO 1442, 1997. International Standards Meat and Meat Products - Determination of Moisture Content. International Organization for Standarization, Geneva, Switzerland.

ISO 936, 1998. International Standards Meat and Meat Products - Determination of Ash Content. International Organization for Standarization, Geneva, Switzerland.

ISO 937, 1978. International Standardsmeat Andmeat Products - Determination of Nitrogen Content. International Organization for Standarization, Geneva, Switzerland.

Jacob, R.H., Pethick, D.W., Chapman, H.M., 2005. Muscle glycogen concentrations in commercial consignments of Australian lamb measured on farm and post-slaughter after three different lairage periods. Aust. J. Exp. Agric. 45, 552. https://doi.org/ 10.1071/EA03216.

Komprda, T., Kuchtík, J., Jarošová, A., Dračková, E., Zemánek, L., Filipčík, B., 2012. Meat quality characteristics of lambs of three organically raised breeds. Meat Sci. 91, 499-505. https://doi.org/10.1016/j.meatsci.2012.03.004.

Koohmaraie, M., Shackelford, S.D., Wheeler, T.L., Lonergan, S.M., Doumit, M.E., 1995 A muscle hypertrophy condition in lamb (callipyge): characterization of effects on muscle growth and meat quality traits. J. Anim. Sci. 73, 3607. https://doi.org/ $10.2527 / 1995.73123596 x$.

Lind, V., Berg, J., Eilertsen, S.M., Hersleth, M., Eik, L.O., 2011. Effect of gender on meat quality in lamb from extensive and intensive grazing systems when slaughtered at the end of the growing season. Meat Sci. 88, 305-310. https://doi.org/10.1016/j. meatsci.2011.01.008.

Majdoub-Mathlouthi, L., Saïd, B., Say, A., Kraiem, K., 2013. Effect of concentrate level and slaughter body weight on growth performances, carcass traits and meat quality of Barbarine lambs fed oat hay based diet. Meat Sci. 93, 557-563. https://doi.org/ 10.1016/j.meatsci.2012.10.012.

Mendelsohn, R., 2003. The challenge of conserving indigenous domesticated animals. Ecol. Econ. 45, 501-510. https://doi.org/10.1016/S0921-8009(03)00100-9.

Molinero, C., 2009. Caracterización Y Optimización Del Proceso Tecnológico De Elaboración De La Cecina De León. Universidad De Burgos (España).

Montossi, F., Font-i-Furnols, M., Campo, M., San Julián, R., Brito, G., Sañudo, C., 2013 Sustainable sheep production and consumer preference trends: Compatibilities, contradictions and unresolved dilemmas. Meat Sci. 95 (4), 772-789. https://doi org/10.1016/j.meatsci.2013.04.048.

Osorio, M.T., Zumalacárregui, J.M., Bermejo, B., Lozano, A., Figueira, A.C., Mateo, J., 2007. Effect of ewe's milk versus milk-replacer rearing on mineral composition of suckling lamb meat and liver. Small Rumin. Res. 68, 296-302. https://doi.org/ 10.1016/j.smallrumres.2005.11.010.

Paraskevopoulou, C., Theodoridis, A., Johnson, M., Ragkos, A., Arguile, L., Smith, L., Vlachos, D., Arsenos, G., 2020. Sustainability assessment of goat and sheep farms: a comparison between European countries. Sustainability 12 (8), 3099. https://doi. org/10.3390/su12083099.

Pardi, M.C., Santos, I.F., Souza, E.R., 2001. Ciência, Higiene E Tecnologia Da Carne Centro Editorial E Gráfico Da Universidade Federal De Goiás, Goiânia, Brasil.

Pateiro, M., Lorenzo, J.M., Diaz, S., Gende, J.A., Fernandez, M., Gonzalez, J., Garcia, L., Rial, F.J., Franco, D., 2013. Meat quality of veal: discriminatory ability of weaning status. Span. J. Agric. Res. 11, 1044-1056. https://doi.org/10.5424/sjar/20131144363.

Perlo, F., Bonato, P., Teira, G., Tisocco, O., Vicentin, J., Pueyo, J., Mansilla, A., 2008. Meat quality of lambs produced in the Mesopotamia region of Argentina finished on different diets. Meat Sci. 79, 576-581. https://doi.org/10.1016/j. meatsci.2007.10.005.

Popova, T., Marinova, P., 2013. Carcass composition and meat quality in lambs reared indoors and on pasture. J. Agric. Sci. Technol. 5, 325-330.

Priolo, A., Micol, D., Agabriel, J., 2001. Effects of grass feeding systems on ruminant meat colour and flavour. a review. Anim. Res. 50, 185-200. https://doi.org/ 10.1051/animres:2001125.

Ramírez-Retamal, J., Morales, R., 2014. Influence of breed and feeding on the main quality characteristics of sheep carcass and meat: a review. Chil. J. Agric. Res. 74, 225-233. https://doi.org/10.4067/S0718-58392014000200015.

Revilla, I., Vivar-Quintana, A.M., Palacios, C., Martínez-Martín, I., HernándezJiménez, M., 2020. Effects of rearing system (organic and conventional) and breed (Churra and Castellana) on fatty acid composition and sensory characteristics of suckling lamb meat produced in north-west Spain. Biol. Agric. Hortic. 1-15. https:// doi.org/10.1080/01448765.2020.1785942.

Ripoll, G., Joy, M., Muñoz, F., Albertí, P., 2008. Meat and fat colour as a tool to trace grass-feeding systems in light lamb production. Meat Sci. 80, 239-248. https://doi. org/10.1016/j.meatsci.2007.11.025.

Ripoll, G., Joy, M., Muñoz, F., 2011. Use of dietary vitamin E and selenium (Se) to increase the shelf life of modified atmosphere packaged light lamb meat. Meat Sci. 87, 88-93. https://doi.org/10.1016/j.meatsci.2010.09.008.

Santos-Silva, J., Bessa, R.J., Santos-Silva, F., 2002. Effect of genotype, feeding system and slaughter weight on the quality of light lambs: II. fatty acid composition of meat. Livest. Prod. Sci. 77, 187-194. https://doi.org/10.1016/S0301-6226(02)00059-3.

Sañudo, C., Campo, M.M., Sierra, I., María, G.A., Olleta, J.L., Santolaria, P., 1997. Breed effect on carcase and meat quality of suckling lambs. Meat Sci. 46, 357-365. https:// doi.org/10.1016/S0309-1740(97)00030-2.

Shackelford, S.D., Wheeler, T.L., Koohmaraie, M., 1997. Effect of the callipyge phenotype and cooking method on tenderness of several major lamb muscles. J. Anim. Sci. 75, 2100-2105.

Shija, D.S., Mtenga, L.A., Kimambo, A.E., Laswai, G.H., Mushi, D.E., Mgheni, D.M., Mwilawa, A.J., Shirima, E.J.M., Safari, J.G., 2013. Chemical composition and meat quality attributes of indigenous sheep and goats from traditional production system in Tanzania. Asian-Australasian J. Anim. Sci. 26, 295-302. https://doi.org/10.5713/ ajas.2012.12432.

Sinclair, L.A., 2007. Nutritional manipulation of the fatty acid composition of sheep meat: a review. J. Agric. Sci. 145 (5), 419-434.

Vieira Da Silva, N., Humberto Vilar Da Silva, J., De Souza Coelho, M., Alves De Oliveira, E.R., De Anchieta Araújo, J., Lúcia De Lima Amâncio, A., 2009. Características de carcaça e carne ovina: uma abordagem das variáveis metodológicas e fatores de influência. Acta Vet. Bras. 2, 103-110. https://doi.org/ 10.21708/avb.2008.2.4.801.

Vyncke, W., 1975. Evaluation of the direct thiobarbituric acid extraction method for determining oxidative rancidity in mackerel. Fette, Seifen, Anstrichm. 77, 239-240. https://doi.org/10.1002/lipi.19750770610.

Warner, R.D., Jacob, R.H., Edwards, J.E.H., McDonagh, M., Pearce, K., Geesink, G., Kearney, G., Allingham, P., Hopkins, D.L., Pethick, D.W., 2010. Quality of lamb meat from the Information Nucleus Flock. Anim. Prod. Sci. 50, 1134. https://doi.org/ 10.1071/AN10129.

Webb, E.C., Casey, N.H., Simela, L., 2005. Goat meat quality. Small Rumin. Res. 60, 153-166. https://doi.org/10.1016/j.smallrumres.2005.06.009. 